\title{
The Treaty Practice of the European Communities in 1990
}

\author{
Frank Emmert*
}

\section{Introduction}

Each year the EJL will publish a survey of international agreements concluded by the European Communities with third states or with international organizations. The survey further includes decisions of international bodies such as Customs Cooperation Committees and their implementation in Community law. Finally it covers all binding unilateral acts of the Community with direct impact on their foreign relations, such as unilateral modifications of the customs regimes with specified third states. Not included are modifications of purely internal legislation, even if they affect external relations indirectly, e.g. modifications of the CCT rules on classification, valuation and origin of goods.

The material is structured as follows:

I. Agreements with EFTA Countries and Unilateral Modifications of the Special Trade Regimes with these Countries

II. Agreements with ACP Countries and with OCT Territories and Unilateral Modifications of the Special Trade Regimes with these Countries

III. Agreements with Associated Countries and Unilateral Modifications of the Special Trade Regimes with these Countries

IV. Agreements with State-Trading Countries other than Modifications of the CCT and the Customs Regime and Unilateral Acts Referring to these Countries

V. Multilateral Conventions and Agreements with NGOs

VI. Agreements with Countries not Enjoying General Preferential Status and Unilateral Modifications of the EC Customs Regime

VII. Community Acts Concerning German Unification

VIII. Community Acts Concerning the Gulf Crisis

* University of Munich. 


\section{Agreements with EFTA Countries and Unilateral Modifications of the Special Trade Regimes with these Countries}

* Information concerning the date of entry into force of the Supplementary Protocols to the Agreement with European Free Trade Association (EFTA) countries, OJ L 27/45, 31 January 1990

* Information concerning the date of entry into force of the Agreement in the form of an Exchange of Letters between the European Economic Community and the Republic of Austria adapting the Agreement of 20 September 1977 concerning certain types of cheese negotiated under Article XXVIII of GATT, OJ L 107/67, 27 April 1990

* Information conceming the date of entry into force of certain Protocols and Agreements between the European Economic Community and the countries of the European Free Trade Association (EFTA), OJ L 116/28, 8 May 1990

\section{'Science'}

90/71 Council Decision of 12 February 1990 concerning the conclusion of a Cooperation Agreement between the European Economic Community and the Republic of Austria on a programme plan to stimulate the international cooperation and interchange needed by European research scientists (Science), Of L 50/1, 26 February 1990

Cooperation Agreement between the European Economic Community and the Republic of Austria on a programme plan to stimulate the international cooperation and interchange needed by European research scientists (Science), OJ L 50/2, 26 February 1990

90/72 Council Decision of 12 February 1990 concerning the conclusion of a Cooperation Agreement between the European Economic Community and the Republic of Finland on a programme plan to stimulate the international cooperation and interchange needed by European research scientists (Science), OJ L 50/8, 26 February 1990

Cooperation Agreement between the European Economic Community and the Republic of Finland on a programme plan to stimulate the international cooperation and interchange needed by European research scientists (Science), OJ L 50/9, 26 February 1990

90/73 Council Decision of 12 February 1990 concerning the conclusion of a Cooperation Agreement between the European Economic Community and the Kingdom of Norway on a programme plan to stimulate the international cooperation and interchange needed by European research scientists (Science), OJ L 50/15, 26 February 1990

Cooperation Agreement between the European Economic Community and the Kingdom of Norway on a programme plan to stimulate the international cooperation and interchange needed by European research scientists (Science), OJ L 50/16, 26 February 1990

Corrigendum to Council Decision 90/73/EEC of 12 February 1990 concerning the conclusion of a Cooperation Agreement between the European Economic Community and the Kingdom of Norway on a programme plan to stimulate the 
international cooperation and interchange needed by European research scientists (Science) (OJ L 50, 26 February 1990), OJ L 60/19, 9 March 1990

90/74 Council Decision of 12 February 1990 concerning the conclusion of a Cooperation Agreement between the European Economic Community and the Kingdom of Sweden on a programme plan to stimulate the international cooperation and interchange needed by European research scientists (Science), OJ L 50/22, 26 February 1990

Cooperation Agreement between the European Economic Community and the Kingdom of Sweden on a programme plan to stimulate the international cooperation and interchange needed by European research scientists (Science), OJ L 50/23, 26 February 1990

90/75 Council Decision of 12 February 1990 concerning the conclusion of a Cooperation Agreement between the European Economic Community and the Swiss Confederation on a programme plan to stimulate the international cooperation and interchange needed by European research scientists (Science), OJ L 50/29, 26 February 1990

Cooperation Agreement between the European Economic Community and the Swiss Confederation on a programme plan to stimulate the intemational cooperation and interchange needed by European research scientists (Science), OJ L $50 / 30,26$ February 1990

\section{Medical and Health Research}

90/129 Council Decision of 26 February 1990 concerning the conclusion of a Cooperation Agreement between the European Economic Community and the Republic of Austria in the field of medical and health research, OJ L 74/8, 20 March 1990

Cooperation Agreement between the European Economic Community and the Republic of Austria in the field of medical and health research, OJ L 74/9, 20 March 1990

90/130 Council Decision of 26 February 1990 concerning the conclusion of a Cooperation Agreement between the European Economic Community and the Republic of Finland in the field of medical and health research, OJ L 74/14, 20 March 1990

Cooperation Agreement between the European Economic Community and the Republic of Finland in the field of medical and health research, OJ L 74/15, 20 March 1990

90/131 Council Decision of 26 February 1990 concerning the conclusion of a Cooperation Agreement between the European Economic Community and the Kingdom of Norway in the field of medical and health research, OJ L 74/20, 20 March 1990

Cooperation Agreement between the European Economic Community and the Kingdom of Norway in the field of medical and health research, OJ L 74/21, 20 March 1990

90/132 Council Decision of 26 February 1990 concerning the conclusion of a Cooperation Agreement between the European Economic Community and the 
Kingdom of Sweden in the field of medical and health research, OJ L 74/26, 20 March 1990

Cooperation Agreement between the European Economic Community and the Kingdom of Sweden in the field of medical and health research, OJ L 74/27, 20 March 1990

90/133 Council Decision of 26 February 1990 concerning the conclusion of a Cooperation Agreement between the European Economic Community and the Swiss Confederation in the field of medical and health research, OJ L 74/32, 20 March 1990

Cooperation Agreement between the European Economic Community and the Swiss Confederation in the field of medical and health research, Of L 74/33, 20 March 1990

\section{Safeguard Measures}

638/90 Council Regulation of 5 March 1990 amending Regulation 2837/72 on safeguard measures provided for in the Agreement between the European Economic Community and the Republic of Austria, OJ L 74/1, 20 March 1990

639/90 Council Regulation of 5 March 1990 amending Regulation 3288/73 on safeguard measures provided for in the Agreement between the European Economic Community and the Republic of Finland, OJ L 74/3, 20 March 1990

640/90 Council Regulation of 5 March 1990 amending Regulation 2843/72 on safeguard measures provided for in the Agreement between the European Economic Community and the Republic of Iceland, OJ L 74/4, 20 March 1990

641/90 Council Regulation of 5 March 1990 amending Regulation 1692/73 on safeguard measures provided for in the Agreement between the European Economic Community and the Kingdom of Norway, OJ L 74/5, 20 March 1990

642/90 Council Regulation of 5 March 1990 amending Regulation 2839/72 on safeguard measures provided for in the Agreement between the European Economic Community and the Kingdom of Sweden, OJ L 74/6, 20 March 1990

643/90 Council Regulation of 5 March 1990 amending Regulation 2841/72 on safeguard measures provided for in the Agreement between the European Economic Community and the Swiss Confederation, OJ L 74/7, 20 March 1990

\section{'Comett II'}

90/190 Council Decision of 29 March 1990 concerning the conclusion of an Agreement between the European Economic Community and the Republic of Austria establishing cooperation in the field of training in the context of the implementation of Comett II (1990-1994), OJ L 102/1, 21 April 1990

Agreement between the European Economic Community and the Republic of Austria establishing cooperation in the field of training in the context of the implementation of Comett II (1990-1994), OJ L 102/2, 21 April 1990

90/191 Council Decision of 29 March 1990 concerning the conclusion of an Agreement between the European Economic Community and the Republic of 
Finland establishing cooperation in the field of training in the context of the implementation of Comett II (1990-1994), OJ L 102/11, 21 April 1990

Agreement between the European Economic Community and the Republic of Finland establishing cooperation in the field of training in the context of the implementation of Comett II (1990-1994), OJ L 102/12, 21 April 1990

90/192 Council Decision of 29 March 1990 concerning the conclusion of an Agreement between the European Economic Community and the Republic of Iceland establishing cooperation in the field of training in the context of the implementation of Comett II (1990-1994), OJ L 102/21, 21 April 1990

Agreement between the European Economic Community and the Republic of Iceland establishing cooperation in the field of training in the context of the implementation of Comett II (1990-1994), OJ L 102/22, 21 April 1990

90/193 Council Decision of 29 March 1990 concerning the conclusion of an Agreement between the European Economic Community and the Kingdom of Norway establishing cooperation in the field of training in the context of the implementation of Comett II (1990-1994), OJ L 102/31, 21 April 1990

Agreement between the European Economic Community and the Kingdom of Norway establishing cooperation in the field of training in the context of the implementation of Comett II (1990-1994), OJ L 102/32, 21 April 1990

90/194 Council Decision of 29 March 1990 concerning the conclusion of an Agreement between the European Economic Community and the Kingdom of Sweden establishing cooperation in the field of training in the context of the implementation of Comett II (1990-1994), OJ L 102/41, 21 April 1990

Agreement between the European Economic Community and the Kingdom of Sweden establishing cooperation in the field of training in the context of the implementation of Comett II (1990-1994), OJ L 102/42, 21 April 1990

90/195 Council Decision of 29 March 1990 concerning the conclusion of an Agreement between the European Economic Community and the Swiss Confederation establishing cooperation in the field of training in the context of the implementation of Comett II (1990-1994), OJ L 102/51, 21 April 1990

Agreement between the European Economic Community and the Swiss Confederation establishing cooperation in the field of training in the context of the implementation of Comett II (1990-1994), OJ L 102/52, 21 April 1990

\section{Decisions of the EEC-EFTA Joint Committees}

1945/90 Council Regulation of 29 June 1990 on the application of Decision No. 1/90 of the EEC-Austria Joint Committee amending Protocol 3 concerning the definition of the concept 'originating products' and methods of administrative cooperation following the suspension of the customs duties applicable by the Community of Ten and Austria to imports from Spain, OJ L 176/1, 10 July 1990

Decision No. 1/90 of the EEC-Austria Joint Committee of 15 May 1990 amending Protocol 3 concerning the definition of the concept 'originating products' and methods of administrative cooperation following the suspension of the customs duties applicable by the Community of Ten and Austria to imports from Spain, OJ L 176/2, 10 July 1990 
1946/90 Council Regulation of 29 June 1990 on the application of Decision No. 1/90 of the EEC-Finland Joint Committee amending Protocol 3 concerning the definition of the concept 'originating products' and methods of administrative cooperation following the suspension of the customs duties applicable by the Community of Ten and Finland to imports from Spain, OJ L 176/3, 10 July 1990

Decision No. 1/90 of the EEC-Finland Joint Committee of 11 April 1990 amending Protocol 3 concerning the definition of the concept 'originating products' and methods of administrative cooperation following the suspension of the customs duties applicable by the Community of Ten and Finland to imports from Spain, OJ L 176/4, 10 July 1990

$1947 / 90$ Council Regulation of 29 June 1990 on the application of Decision No. 1/90 of the EEC-Iceland Joint Committee amending Protocol 3 concerning the definition of the concept 'originating products' and methods of administrative cooperation following the suspension of the customs duties applicable by the Community of Ten and Iceland to imports from Spain, OJ L 176/5, 10 July 1990

Decision No. 1/90 of the EEC-Iceland Joint Committee of 15 May 1990 amending Protocol 3 concerning the definition of the concept 'originating products' and methods of administrative cooperation following the suspension of the customs duties applicable by the Community of Ten and Iceland to imports from Spain, OJ L 176/6, 10 July 1990

1948/90 Council Regulation of 29 June 1990 on the application of Decision No. 1/90 of the EEC-Norway Joint Committee amending Protocol 3 conceming the definition of the concept 'originating products' and methods of administrative cooperation following the suspension of the customs duties applicable by the Community of Ten and Norway to imports from Spain, OJ L 176/7, 10 July 1990

Decision No. 1/90 of the EEC-Norway Joint Committee of 2 May 1990 amending Protocol 3 concerning the definition of the concept 'originating products' and methods of administrative cooperation following the suspension of the customs duties applicable by the Community of Ten and Norway to imports from Spain, OJ L 176/8, 10 July 1990

1949/90 Council Regulation of 29 June 1990 on the application of Decision No. 1/90 of the EEC-Sweden Joint Committee amending Protocol 3 concerning the definition of the concept 'originating products' and methods of administrative cooperation following the suspension of the customs duties applicable by the Community of Ten and Sweden to imports from Spain, OJ L 176/9, 10 July 1990

Decision No. 1/90 of the EEC-Sweden Joint Committee of 23 April 1990 amending Protocol 3 concerning the definition of the concept 'originating products' and methods of administrative cooperation following the suspension of the customs duties applicable by the Community of Ten and Sweden to imports from Spain, OJ L 176/10, 10 July 1990

1950/90 Council Regulation of 29 June 1990 on the application of Decision No. 1/90 of the EEC-Switzerland Joint Committee amending Protocol 3 concerning the definition of the concept 'originating products' and methods of administrative cooperation following the suspension of the customs duties applicable by the 
Community of Ten and Switzerland to imports from Spain, OJ L 176/11, 10 July 1990

Decision No. 1/90 of the EEC-Switzerland Joint Committee of 2 May 1990 amending Protocol 3 conceming the definition of the concept 'originating products' and methods of administrative cooperation following the suspension of the customs duties applicable by the Community of Ten and Switzerland to imports from Spain, OJ L 176/12, 10 July 1990

2291/90 Commission Regulation of 26 July 1990 on the application of Decision 2/90 of the EEC-Austria Joint Committee supplementing and amending Annex III to Protocol No. 3 concerning the definition of the concept of 'originating products' and methods of administrative cooperation, OJ L 210/1, 8 August 1990

Decision 2/90 of the EEC-Austria Joint Committee of 15 May 1990 supplementing and amending, in the framework of the Joint Declaration concerning the review of the changes to the origin rules as a result of the introduction of the harmonized system, Annex III to Protocol No. 3 concerning the definition of the concept 'originating products' and methods of administrative cooperation, OJ L 210/2, 8 August 1990

2292/90 Commission Regulation of 26 July 1990 on the application of Decision 2/90 of the EEC-Finland Joint Committee supplementing and amending Annex III to Protocol No. 3 concerning the definition of the concept of 'originating products' and methods of administrative cooperation, OJ L 210/5, 8 August 1990

Decision 2/90 of the EEC-Finland Joint Committee of 11 April 1990 supplementing and amending, in the framework of the Joint Declaration conceming the review of the changes to the origin rules as a result of the introduction of the harmonized system, Annex III to Protocol No. 3 concerning the definition of the concept 'originating products' and methods of administrative cooperation, OJ L 210/6, 8 August 1990

2293/90 Commission Regulation of 26 July 1990 on the application of Decision 2/90 of the EEC-Iceland Joint Committee supplementing and amending Annex III to Protocol No. 3 concerning the definition of the concept of 'originating products' and methods of administrative cooperation, OJ L 210/9, 8 August 1990

Decision 2/90 of the EEC-Iceland Joint Committee of 15 May 1990 supplementing and amending, in the framework of the Joint Declaration concerning the review of the changes to the origin rules as a result of the introduction of the harmonized system, Annex III to Protocol No. 3 concerning the definition of the concept 'originating products' and methods of administrative coooperation, OJ L 210/10, 8 August 1990

2294/90 Commission Regulation of 26 July 1990 on the application of Decision 2/90 of the EEC-Norway Joint Committee supplementing and amending Annex III to Protocol 3 concerning the definition of the concept of 'originating products' and methods of administrative cooperation, OJ L 210/13, 8 August 1990

Decision 2/90 of the EEC-Norway Joint Committee of 2 May 1990 supplementing and amending, in the framework of the Joint Declaration concerning the review of the changes to the origin rules as a result of the introduction of the harmonized system, Annex III to Protocol 3 concerning the definition of the concept 'originating products' and methods of administrative cooperation, OJ L 210/14, 8 August 1990 
2295/90 Commission Regulation of 26 July 1990 on the application of Decision 2/90 of the EEC-Sweden Joint Committee supplementing and amending Annex III to Protocol 3 concerning the definition of the concept of 'originating products' and methods of administrative cooperation, OJ L 210/17, 8 August 1990

Decision 2/90 of the EEC-Sweden Joint Committee of 23 April 1990 supplementing and amending, in the framework of the Joint Declaration concerning the review of the changes to the origin rules as a result of the introduction of the harmonized system, Annex III to Frotocol 3 concerning the definition of the concept 'originating products' and methods of administrative cooperation, OJ L 210/18, 8 August 1990

2296/90 Commission Regulation of 26 July 1990 on the application of Decision 2/90 of the EEC-Switzerland Joint Committee supplementing and amending Annex III to Protocol 3 concerning the definition of the concept of 'originating products' and methods of administrative cooperation, OJ L 210/21, 8 August 1990

Decision 2/90 of the EEC-Switzerland Joint Committee of 2 May 1990 supplementing and amending, in the framework of the Joint Declaration concerning the review of the changes to the origin rules as a result of the introduction of the harmonized system, Annex III to Protocol 3 concerning the definition of the concept 'originating products' and methods of administrative cooperation, OJ L 210/22, 8 August 1990

2144/90 Council Regulation of 16 July 1990 on the application of Decision 3/90 of the EEC-Austria Joint Committee amending Protocol 3 concerning the definition of the concept of 'originating products' and methods of administrative cooperation, OJ L 199/1, 30 July 1990

Decision No. 3/90 of the EEC-Austria Joint Committee of 18 June 1990 amending Protocol 3 concerning the definition of the concept of 'originating products' and methods of administrative cooperation, OJ L 199/2, 30 July 1990

2145/90 Council Regulation of 16 July 1990 on the application of Decision No. 3/90 of the EEC-Finland Joint Committee amending Protocol 3 concerning the definition of the concept of 'originating products' and methods of administrative cooperation, OJ L 199/3, 30 July 1990

Decision No. 3/90 of the EEC-Finland Joint Committee of 5 June 1990 amending Protocol 3 concerning the definition of the concept of 'originating products' and methods of administrative cooperation, OJ L 199/4, 30 July 1990

2146/90 Council Regulation of 16 July 1990 on the application of Decision No. 3/90 of the EEC-Iceland Joint Committee amending Protocol 3 concerning the definition of the concept of 'originating products' and methods of administrative cooperation, OJ L 199/5, 30 July 1990

Decision No. 3/90 of the EEC-Norway Joint Committee of 18 June 1990 amending Protocol 3 concerning the definition of the concept of 'originating products' and methods of administrative cooperation, OJ L 199/6, 30 July 1990

2147/90 Council Regulation of 16 July 1990 on the application of Decision No. 3/90 of the EEC-Norway Joint Committee amending Protocol 3 concerning the definition of the concept of 'originating products' and methods of administrative cooperation, OJ L $199 / 7,30$ July 1990 
Decision No. 3/90 of the EEC-Norway Joint Committee of 19 June 1990 amending Protocol 3 concerning the definition of the concept of 'originating products' and methods of administrative cooperation, OJ L 199/8, 30 July 1990

2148/90 Council Regulation of 16 July 1990 on the application of Decision No. 3/90 of the EEC-Sweden Joint Committee amending Protocol 3 concerning the definition of the concept of 'originating products' and methods of administrative cooperation, OJ L 199/9, 30 July 1990

Decision No. 3/90 of the EEC-Sweden Joint Committee of 15 June 1990 amending Protocol 3 concerning the definition of the concept of 'originating products' and methods of administrative cooperation, OJ L 199/10, 30 July 1990

2149/90 Council Regulation of 16 July 1990 on the application of Decision No. 3/90 of the EEC-Switzerland Joint Committee amending Protocol 3 concerning the definition of the concept of 'originating products' and methods of administrative cooperation, OJ L 199/11, 30 July 1990

Decision No. 3/90 of the EEC-Switzerland Joint Committee of 8 June 1990 amending Protocol 3 concerning the definition of the concept of 'originating products' and methods of administrative cooperation, OJ L 199/12, 30 July 1990

2297/90 Commission Regulation of 26 July 1990 on the application of Decision 4/90 of the EEC-Austria Joint Committee supplementing and amending Annex III to Protocol 3 conceming the definition of the concept of 'originating products' and methods of administrative cooperation, OJ L 210, p 25, 8 August 1990

Decision 4/90 of the EEC-Austria Joint Committee of 18 June 1990 supplementing and amending, in the framework of the Joint Declaration concerning the review of the changes to the origin rules as a result of the introduction of the harmonized system, Annex III to Protocol 3 concerning the definition of the concept of 'originating products' and methods of administrative cooperation, OJ L 210/26, 8 August 1990

2298/90 Commission Regulation of 26 July 1990 on the application of Decision 4/90 of the EEC-Finland Joint Committee supplementing and amending Annex III to Protocol 3 concerning the definition of the concept of 'originating products' and methods of administrative cooperation, OJ L 210/27, 8 August 1990

Decision 4/90 of the EEC-Finland Joint Committee of 5 June 1990 supplementing and amending, in the framework of the Joint Delaration concerning the review of the changes to the origin rules as a result of the introduction of the harmonized system, Annex III to Protocol 3 concerning the definition of the concept of 'originating products' and methods of administrative cooperation, OJ L 210/28, 8 August 1990

2299/90 Commission Regulation of 26 July 1990 on the application of Decision 4/90 of the EEC-Iceland Joint Committee supplementing and amending Annex III to Protocol 3 concerning the definition of the concept of 'originating products' and methods of administrative cooperation, OJ L 210/29, 8 August 1990

Decision 4/90 of the EEC-Iceland Joint Committee of 18 June 1990 supplementing and amending, in the framework of the Joint Declaration concerning the review of the changes to the origin rules as a result of the introduction of the harmonized system, Annex III to Protocol 3 concerning the definition of 
the concept of 'originating products' and methods of administrative cooperation, OJ L 210/30, 8 August 1990

2300/90 Commission Regulation of 26 July 1990 on the application of Decision 4/90 of the EEC-Norway Joint Committee supplementing and amending Annex III to Protocol 3 concerning the definition of the concept of 'originating products' and methods of administrative cooperation, OJ L 210/31, 8 August 1990

Decision 4/90 of the EEC-Norway Joint Committee of 19 June 1990 supplementing and amending, in the framework of the Joint Declaration concerning the review of the changes to the origin rules as a result of the introduction of the harmonized system Annex III to Protocol 3 concerning the definition of the concept of 'originating products' and methods of administrative cooperation, OJ L 210/32, 8 August 1990

2301/90 Commission Regulation of 26 July 1990 on the application of Decision 4/90 of the EEC-Sweden Joint Committee supplementing and amending Annex III to Protocol 3 concerning the definition of the concept of 'originating products' and methods of administrative cooperation, OJ L 210/33, 8 August 1990

Decision 4/90 of the EEC-Sweden Joint Committee of 15 June 1990 supplementing and amending in the framework of the Joint Declaration concerning the review of the changes to the origin rules as a result of the introduction of the harmonized system, Annex III to Protocol 3 concerning the definition of the concept of 'originating products' and methods of administrative cooperation, OJ L 210/34, 8 August 1990

2302/90 Commission Regulation of 26 July 1990 on the application of Decision 4/90 of the EEC-Switzerland Joint Committee supplementing and amending Annex III to Protocol 3 concerning the definition of the concept of 'originating products' and methods of administrative cooperation, OJ L 210/35, 8 August 1990

Decision 4/90 of the EEC-Switzerland Joint Committee of 8 June 1990 supplementing and amending, in the framework of the Joint Declaration concerning the review of the changes to the origin rules as a result of the introduction of the harmonized system, Annex III to Protocol 3 concerning the definition of the concept of 'originating products' and methods of administrative cooperation, OJ L 210/36, 8 August 1990

2042/90 Commission Regulation of 10 July 1990 on the application of Decision No. 5/90 of the EEC-Iceland Joint Committee supplementing and amending Annex III to Protocol 3 concerning the definition of the concept 'originating products' and methods of administrative cooperation, OJ L 187/15, 19 July 1990

Decision No. 5/90 of the EEC-Iceland Joint Committee of 18 June 1990 supplementing and amending, in the framework of the Joint Declaration concerning the review of the changes to the origin rules as a result of the introduction of the harmonized system, Annex III to Protocol 3 concerning the definition of the concept 'originating products' and methods of administrative cooperation, OJ L 187/16, 19 July 1990

Corrigendum to Decision 5/90 of the EEC-Iceland Joint Committee of 18 June 1990 supplementing and amending, in the framework of the Joint Decision conceming the review of the changes to the origin rules as a result of the introduction of the harmonized system, Annex III to Protocol 3 concerning the definition of the concept of 'originating products' and methods of administrative cooperation (OJ L 187 of 19 July 1990), OJ L 216/28, 11 August 1990 
1052/90 Council Regulation of 23 April 1990 on the application of Decision 2/89 of the EEC/EFTA Joint Committee on common transit amending the Convention of 20 May 1987 on a common transit procedure, OJ L 108/3, 28 April 1990

Decision 2/89 of the EEC/EFTA Joint Committee on common transit amending the Convention of 20 May 1987 on a common transit procedure, OJ L 108/4, 28 April 1990

\section{Agreements on Other Subject Matters}

90/23 Council Decision of 29 September 1989 concerning the conclusion, on behalf of the European Economic Community, of the Framework Agreement for scientific and technical cooperation between the European Communities and the Republic of Iceland, OJ L 14/18, 18 January 1990

Framework Agreement for scientific and technical cooperation between the European Communities and the Republic of Iceland, OJ L 14/19, 18 January 1990

90/24 Commission Decision of 12 January 1990 concerning the final conclusion, on behalf of the European Atomic Energy Community, of the Framework Agreement for scientific and technical cooperation between the European Communities and the Republic of Iceland, OJ L 14/22, 18 January 1990

90/160 Council Decision of 22 March 1990 concerning the conclusion of the Agreement between the Federal Republic of Germany and the European Economic Community, on the one hand, and the Repulic of Austria, on the other, on cooperation on management of water resources in the Danube Basin, OJ L 90/18, 5 April 1990

Agreement between the Federal Republic of Germany and the European Economic Community, on the one hand, and the Repulic of Austria, on the other, on cooperation on management of water resources in the Danube Basin, OJ L 90/20, 5 April 1990

90/216 Council Decision of 23 April 1990 concerning the conclusion of the Agreement between the European Economic Community and the Swiss Confederation on the simplification of inspections and formalities in respect of the carriage of goods, OJ L 116/18, 8 May 1990

Agreement between the European Economic Community and the Swiss Confederation on the simplification of inspections and formalities in respect of the carriage of goods, OJ L 116/19, 8 May 1990

90/447 Commission Decision of 30 July 1990 concerning the conclusion of a cooperation agreement between the European Atomic Energy Community and the Kingdom of Sweden on research and training in the field of radiation protection, OJ L 228/35, 22 August 1990

Cooperation Agreement between the European Atomic Energy Community and the Kingdom of Sweden on research and training in the field of radiation protection, OJ L 228/36, 22 August 1990

90/518 Council Decision of 24 September 1990 concerning the conclusion of an Agreement between the European Economic Community, on the one hand, and the Republic of Austria, the Republic of Finland, the Republic of Iceland, the Kingdom of Norway, the Kingdom of Sweden and the Swiss Confederation, on 
the other, laying down a procedure for the exchange of information in the field of technical regulations, OJ L 291/1, 23 October 1990

Agreement laying down a procedure for the exchange of information in the field of technical regulations, Of L 291/2, 23 October 1990

Information concerning the conclusion of an Agreement between the European Economic Commumitiy, on the one hand, and the Republic of Austria, the Republic of Finland, the Republic of Iceland, the Kingdom of Norway, the Kingdom of Sweden and the Swiss Confederation, on the other, laying down a procedure for the exchange of information in the field of technical regulations, Of L 291/43, 23 October 1990

\section{Unilateral Acts}

$107 / 90$ Commission Regulation of 16 January 1990 amending Regulation 1767/82 as regards certain cheese from Switzerland and Austria, OJ L 13/13, 17 January 1990

183/90 Commission Regulation of 25 January 1990 setting for 1990 the quantities of cheese originating in and coming from Switzerland that may be imported into Spain, OJ L 21/38, 26 January 1990

1525/90 Commission Regulation of 6 June 1990 amending Regulation 788/86 fixing the free-at-frontier values applicable to imports of certain cheeses originating in and consigned from Switzerland for the 1990/91 milk year, OJ L 144/15, 7 June 1990

2222/90 Commission Regulation of 30 July 1990 amending Regulation 183/90 setting for 1990 the quantities of cheese originating in and coming from Switzerland that may be imported into Spain, OJ L 202/32, 31 July 1990

3632/90 Commission Regulation of 17 December 1990 setting for 1991 the quantities of cheese originating in and coming from Switzerland that may be imported into Spain, OJ L 355/9, 18 December 1990

90/90 Commission Decision of 2 March 1990 concerning importation by Member States of live pigs, fresh pigmeat and pigmeat products from Austria, OJ L $61 / 21,10$ March 1990

1255/90 Council Regulation of 7 May 1990 opening and providing for the administration of Community tariff quotas for certain quality wines and sparkling wines, originating in Austria, OJ L 124/1, 15 May 1990

$3403 / 90$ Council Regulation of 19 November 1990 opening, allocating and providing for the administration of a Community tariff quota for frozen peas originating in Sweden (1991), OJ L 328/4, 28 November 1990

3404/90 Council Regulation of 19 November 1990 opening and providing for the administration of Community tariff quotas for cod and fish of the species Boreogadus saida, dried, salted or in brine, originating in Norway (1991), OJ L 328/6, 28 November 1990

3523/90 Council Regulation of 4 December 1990 opening and providing for the administration of Community tariff quotas for certain agricultural and fishery products originating in certain EFTA countries, OJ L 343/4, 7 December 1990 
Frank Emmert

\section{Agreements with ACP Countries and with OCT Territories and Unilateral Modifications of the Special Trade Regimes with these Countries}

\section{Agreements on Fisheries}

* Information on the date of entry into force of the Agreement in the form of an Exchange of Letters concerning the provisional application of the Agreement amending the Agreement between the European Economic Community and the Government of the Democratic Republic of São Tome and Príncipe on fishing off São Tome and Príncipe, signed at Brussels on 1 February 1984, with effect from 1 June 1987, OJ L 129/36, 19 May 1990

90/621 Council Decision of 22 October 1990 on the conclusion of the Agreument in the form of an Exchange of Letters concerning the provisional application of the Protocol establishing, for the period 1 June 1990 to 31 May 1993, the fishing rights and financial compensation provided for in the Agreement between the European Economic Community and the Government of the Democratic Republic of São Tomé e Príncipe on fishing off São Tomé e Príncipe, OJ L 334/1, 30 November 1990

Agreement in the form of an Exchange of Letters concerning the provisional application of the Protocol establishing, for the period 1 June 1990 to 31 May 1993, the fishing rights and financial compensation provided for in the Agreement between the European Economic Community and the Government of the Democratic Republic of São Tomé e Príncipe on fishing off São Tomé e Príncipe, OJ L 334/3, 30 November 1990

Protocol establishing fishing rights and financial compensation for the period 1 June 1990 to 31 May 1993, OJ L 334/4, 30 November 1990

90/41 Council Decision of 22 January 1990 on the conclusion of an Agreement in the form of an Exchange of Letters concerning the provisional application of the Protocol establishing, for the period from 1 January 1990 to 31 December 1991, the fishing opportunities and the financial contribution provided for in the Agreement between the European Economic Community and the Government of the People's Republic of Mozambique on fisheries relations, OJ L 22/74, 27 January 1990

Agreement in the form of an Exchange of Letters concerning the provisional application of the Protocol establishing, for the period from 1 January 1990 to 31 December 1991, the fishing opportunities and the financial contribution provided for in the Agreement between the European Economic Community and the Government of the People's Republic of Mozambique on fisheries relations, OJ L 22/75, 27 January 1990

$1454 / 90$ Council Regulation of 28 May 1990 relating to the conclusion of the Protocol establishing, for the period 1 January 1990 to 31 December 1991, the fishing opportunities and the financial contribution provided for in the Agreement between the European Economic Community and the Government of the People's Republic of Mozambique on fisheries relations, OJ L 140/1, 1 June 1990

Protocol establishing, for the period 1 January 1990 to 31 December 1991, the fishing opportunities and the financial contribution provided for in the Agreement between the European Economic Community and the Government of 
the People's Republic of Mozambique on fisheries relations, OJ L 140/2, 1 June 1990

$1235 / 90$ Council Regulation of 25 April 1990 on the conclusion of the Protocol establishing for the period of 16 June 1989 to 15 June 1991 the fishing rights and financial compensation provided for in the Agreement between the European Economic Community and the Republic of Guinea-Bissau on fishing off the coast of Guinea-Bissau, OJ L 125/1, 15 May 1990

Protocol establishing for the period of 16 June 1989 to 15 June 1991 the fishing rights and financial compensation provided for in the Agreement between the European Economic Community and the Government of the Republic of Guinea-Bissau on fishing off the coast of Guinea-Bissau, OJ L 125/3, 15 May 1990

1236/90 Council Regulation of 25 April 1990 on the conclusion of the Protocol establishing for the period of 27 June 1989 to 26 June 1991 the fishing rights and financial compensation provided for in the Agreement between the European Economic Community and the Government of the Republic of Equatorial Guinea on fishing off the coast of Equatorial Guinea, OJ L 125/17, 15 May 1990

Protocol establishing for the period of 27 June 1989 to 26 June 1991 the fishing rights and financial compensation provided for in the Agreement between the European Economic Community and the Government of the Republic of Equatorial Guinea on fishing off the coast of Equatorial Guinea, OJ L 125/18, 15 May 1990

$1237 / 90$ Council Regulation of 25 April 1990 on the conclusion of the Agreement between the European Economic Community and the Republic of Sierra Leone on fishing off Sierra Leone, OJ L 125/27, 15 May 1990

Agreement between the European Economic Community and the Republic of Sierra Leone on fishing off Sierra Leone, OJ L 125/28, 15 May 1990

Protocol on the fishing rights and financial contribution provided for in the Agreement between the European Economic Community and the Republic of Sierra Leone on fishing off Sierra Leone, OJ L 125/36, 15 May 1990

90/226 Council Decision of 25 April 1990 on the conclusion of the Agreement in the form of an Exchange of Letters concerning the provisional application of the Protocol defining for the period 18 January 1990 to 17 January 1993 the fishing opportunities and the financial contribution provided for by the Agreement between the European Economic Community and the Republic of Seychelles on fishing off the coast of Seychelles, OI L 125/37, 15 May 1990

Agreement in the form of an Exchange of Letters concerning the provisional application of the Protocol defining, for the period 18 January 1990 to 17 January 1993, the fishing opportunities and the financial contribution provided for by the Agreement between the European Economic Community and the Republic of Seychelles on fishing off Seychelles, OJ L 125/38, 15 May 1990

Protocol defining for the period 18 January 1990 to 17 January 1993 the fishing opportunities and the financial contribution provided for by the Agreement between the European Economic Community and the Republic of Seychelles on fishing off Seychelles, OJ L 125/39, 15 May 1990 
3193/90 Council Regulation of 29 October 1990 on the conclusion of the Protocol defining, for the period from 18 January 1990 to 17 January 1993, the fishing opportunities and the financial contribution provided for by the Agreement between the European Economic Community and the Republic of Seychelles on fishing off Seychelles, OJ L 306/1. 6 November 1990

Protocol defining, for the period from 18 January 1990 to 17 January 1993, the fishing opportunities and the financial contribution provided for by the Agreement between the European Economic Community and the Republic of Seychelles on fishing off Seychelles, OJ L 306/2, 6 November 1990

90/227 Council Decision of 7 May 1990 on the conclusion of the Agreement in the form of an Exchange of Letters concerning the provisional application of the Protocol establishing, for the period from 1 January 1990 to 31 December 1991, the fishing rights and the financial compensation provided for in the Agreement between the European Economic Community and the Government of the Republic of Guinea on fishing off the Guinean coast, OJ L 125/43, 15 May 1990

Agreement in the form of an Exchange of Letters concerning the provisional application of the Protocol establishing, for the period 1 January 1990 to 31 December 1991, the fishing rights and the financial compensation provided for in the Agreement between the European Economic Community and the Government of the Republic of Guinea on fishing off the Guinean coast, OJ L 125/45, 15 May 1990

Protocol establishing for the period 1 January 1990 to 31 December 1991 the fishing rights and the financial compensation provided for in the Agreement between the European Economic Community and the Government of the Republic of Guinea on fishing off the Guinean coast, OJ L 125/46, 15 May 1990

2322/90 Council Regulation of 24 July 1990 on the conclusion of the Protocol establishing, for the period 1 January 1990 to 31 December 1991, the fishing rights and financial compensation provided for in the Agreement between the European Economic Community and the Government of the Republic of Guinea on fishing off the coast of Guinea, OJ L 212/14, 9 August 1990

Protocol establishing, for the period 1 January 1990 to 31 December 1991, the fishing rights and financial compensation provided for in the Agreement between the European Economic Community and the Government of the Republic of Guinea on fishing off the Guinean coast, OJ L 212/16, 9 August 1990

90/263 Council Decision of 7 June 1990 concluding an Agreement in the form of an Exchange of Letters concerning the temporary extension from 1 to 31 March 1990 of the Protocol to the Agreement between the Government of the Republic of Senegal and the European Economic Community on fishing off the coast of Senegal, OJ L 150/20, 14 June 1990

Agreement in the form of an Exchange of Letters concerning the temporary extension from 1 to 31 March 1990 of the Protocol to the Agreement between the Government of the Republic of Senegal and the European Economic Community on fishing off the coast of Senegal, OJ L 150/21, 14 June 1990

90/405 Council Decision of 27 July 1990 on the conclusion of an Agreement in the form of an Exchange of Letters temporaily extending from 1 to 30 April 1990 the Protocol to the Agreements between the European Economic Community 
and the Government of the Republic of Senegal on fishing off the coast of Senegal, OJ L 208/31, 7 August 1990

Agreement in the form of an Exchange of Letters temporarily extending from 1 to 30 April 1990 the Protocol to the Agreement between the European Economic Community and the Government of the Republic of Senegal on fishing off the coast of Senegal, OJ L 208/32, 7 August 1990

90/407 Council Decision of 27 July 1990 on the conclusion of an Agreement in the form of an Exchange of Letters concerning the provisional application of the Protocol setting out the fishing rights and financial compensation provided for in the Agreement between the Government of the Republic of Senegal and the European Economic Community on fishing off the coast of Senegal for the period from 1 May 1990 to 30 April 1992, OJ L 208/36, 7 August 1990

Agreement in the form of an Exchange of Letters on the provisional application of the Protocol defining, for the period from 1 May 1990 to 30 April 1992, the fishing rights and financial compensation provided for in the Agreement between the Government of the Republic of Senegal and the European Economic Community on fishing off the coast of Senegal, OJ L 208/38, 7 August 1990

* Information on the date of entry into force of the Protocol deining, for the period 21 May 1989 to 20 May 1992, the fishing opportunities and the financial contribution provided for by the Agreement between the European Economic Community and the Government of the Democratic Republic of Madagascar on fishing off Madagascar, OJ L 190/46, 21 July 1990

Information on the date of signing of the Agreement in the form of an Exchange of Letters concerning the provisional application of the Protocol defining, for the period 21 May 1989 to 20 May 1992, the fishing opportunities and the financial contribution provided for by the Agreement between the European Economic Community and the Government of the Democratic Republic of Madagascar on fishing off Madagascar, OJ L 190/49, 21 July 1990

2321/90 Council Regulation of 24 July 1990 on the conclusion of the Agreement between the European Economic Community and the Republic of Cape Verde on fishing off Cape Verde, OJ L 212/1, 9 August 1990

Agreement between the European Economic Community and the Republic of Cape Verde on fishing off the coast of Cape Verde, OJ L 212/3, 9 August 1990

Protocol establishing the fishing rights and financial compensation provided for in the Agreement between the European Economic Community and the Republic of Cape Verde on fishing off the coast of Cape Verde, OJ L 212/13, 9 August 1990

90/406 Council Decision of 27 July 1990 on the conclusion of an Agreement in the form of an Exchange of Letters conceming the provisional application of the Protocol establishing for the period from 1 July 1990 to 30 June 1993 the fishing rights and financial compensation provided for in the Agreement between the European Economic Community and the Government of the Republic of the Gambia on fishing off the Gambia, OJ L 208/34, 7 August 1990

Agreement in the form of an Exchange of Letters concerning the provisional application of the Protocol establishing for the period from 1 July 1990 to 30 June 1993 the fishing rights and financial compensation provided for in the Agreement between the European Economic Community and the Government of 
the Republic of the Gambia on fishing off the Gambia, OJ L 208/35, 7 August 1990

90/409 Council Decision of 27 July 1990 on the conclusion of the Agreement in the form of an Exchange of Letters on the provisional application of the Protocol establishing, for the period from 3 May 1990 to 2 May 1992, the fishing opportunities and financial compensation provided for in the Agreement between the European Economic Community and the Government of the People's Republic of Angola on fishing off Angola, OJ L 208/41, 7 August 1990

Agreement in the form of an Exchange of Letters on the provisional application of the Protocol establishing, for the period from 3 May 1990 to 2 May 1992, the fishing opportunities and financial compensation provided for in the Agreement between the European Economic Community and the Government of the People's Republic of Angola on fishing off Angola, OJ L 208/42, 7 August 1990

90/532 Council Decision of 15 October 1990 on the conclusion of an Agreement in the form of an Exchange of Letters concerning the temporary extension from 1 to 31 July 1990 of the Agreement between the European Economic Community and the Islamic Republic of Mauritania on fishing off the coast of Mauritania, OJ L 296/60, 27 October 1990

Agreement in the form of an Exchange of Letters concerning the temporary extension from 1 to 31 July 1990 of the Agreement between the European extension from 1 to 31 July 1990 of the Agreement between the European Economic Community and the Islamic Republic of Mauritania on fishing off the coast of Mauritania, OJ L 296/61, 27 October 1990

90/622 Council Decision of 12 November 1990 on the conclusion of the Agreement in the form of an Exchange of Letters concerning the provisional application of the Protocol setting out, for the period 1 August 1990 to 31 July 1993, the fishing opportunities and financial contribution provided for in the Agreement between the European Economic Community and the Islamic Republic of Mauritania on fishing off the coast of Mauritania, OJ L 334/9, 30 November 1990

Agreement in the form of an Exchange of Letters concerning the provisional application of the Protocol setting out, for the period 1 August 1990 to 31 July 1993, the fishing opportunities and financial contribution provided for in the Agreement between the European Economic Community and the Islamic Republic of Mauritania on fishing off the coast of Mauritania, OJ L 334/11, 30 November 1990

Protocol setting out the fishing opportunities and financial contribution provided for in the Agreement between the European Economic Community and the Islamic Republic of Mauritania on fishing off the coast of Mauritania for the period 1 August 1990 to 31 July 1993, OJ L 334/12, 30 November 1990

* Information on the date of entry into force of an Agreement between the European Economic Community and Mauritius on fishing off Mauritius, OJ L 346/17, 11 December 1990

$2647 / 90$ Council Regulation of 16 July 1990 on the conclusion of the Second Protocol laying down the conditions relating to fishing provided for in the Agreement on fisheries between the European Economic Community, on the one hand, and 
the Government of Denmark and the local Government of Greenland, on the other hand, OJ L 252/1, 15 September 1990

Second Protocol laying down the conditions relating to fishing provided for in the Agreement on fisheries between the European Economic Community, on the one hand, and the Government of Denmark and the local Government of Greenland, on the other hand, OJ L 252/2, 15 September 1990

Information on the date of entry into force of the second fisheries Protocol between the European Economic Community and the Government of Denmark and the Home Rule Government of Greenland, OJ L 252/42, 15 May 1990

\section{Decisions by the ACP-EEC Council of Ministers}

714/90 Council Regulation of 5 March 1990 concerning the application of Decision 2/90 of the ACP-EEC Council of Ministers on transitional measures to be applied from 1 March 1990, OJ L 84/1, 30 March 1990

Decision 2/90 of the ACP-EEC Council of Ministers of 27 February 1990 on transitional measures to be applied from 1 March 1990, OJ L 84/2, 30 March 1990

\section{Decisions of the Customs Cooperation Committees}

$310 / 90$ Council Regulation of 5 February 1990 regarding the application of Decision $1 / 90$ of the ACP-EEC Customs Cooperation Committee derogating from the definition of the concept of 'originating products' to take account of the special situation of Mauritius with regard to its production of canned tuna, OJ L 35/1, 7 February 1990

Decision 1/90 of the ACP-EEC Customs Cooperation Committee of 11 January 1990 derogating from the definition of the concept of 'originating products' to take account of the special situation of Mauritius with regard to its production of canned tuna, OJ L 35/2, 7 February 1990

90/401 Decision 2/90 of the ACP-EEC Customs Cooperation Committee of 20 June 1990 derogating from the definition of the concept of 'originating products' to take account of the special situation of Mauritius with regard to its production of canned tuna, OJ L 206/30, 4 August 1990

\section{Customs Arrangements for Specific Products}

90/147 Decision of the representatives of the governments of the Member States, meeting within the Council, of 5 March 1990 on the opening of tariff preferences for products within the province of the ECSC Treaty originating in the overseas countries and territories associated with the Community, OJ L 84/109, 30 March 1990

715/90 Council Regulation of 5 March 1990 on the arrangements applicable to agricultural products and certain goods resulting from the processing of agricultural products originating in the ACP States or in the overseas countries and territories (OCT), OJ L 84/85, 30 March 1990 
Corrigendum to Council Regulation 715/90 of 5 March 1990 on the arrangements applicable to agricultural products and certain goods resulting from the processing of agricultural products originating in the ACP States or in the overseas countries and territories (OCT) (OJ L 84 of 30 March 1990), OJ L 131/34, 23 May 1990

Corrigendum to Council Regulation 715/90 of 5 March 1990 on the arrangements applicable to agricultural products and certain goods resulting from the processing of agricultural products originating in the ACP States or in the overseas countries and territories (OCT) (OJ L 84 of 30 March 1990), OJ L 276/46, 6 October 1990

825/90 Commission Regulation of 6 March 1990 opening and providing for the administration of Community tariff quotas for certain agricultural products originating in the African, Caribbean and Pacific States or in the overseas countries and territories (1990), OJ L 86/7, 31 March 1990

836/90 Commission Regulation of 28 March 1990 on the arrangement applicable to agricultural products subject to reference quantities and originating in the African, Caribbean and Pacific States or in the overseas countries and territories (1990), OJ L 86/10, 31 March 1990

865/90 Commission Regulation of 4 April 1990 laying down detailed rules for the application of the special arrangements for imports of grain sorghum and millet originating in the African, Caribbean and Pacific States (ACP) or in the overseas countries and territories (OCT), OJ L 90/16, 5 April 1990

903/90 Commission Regulation of 9 April 1990 laying down detailed rules for the application of the arrangements applicable to imports of certain poultrymeat products originating in the African, Caribbean and Pacific States (ACP) or in the overseas countries and territories (OCT), OJ L 93/20, 10 April 1990

904/90 Commission Regulation of 9 April 1990 laying down detailed rules for the application of the arrangements applicable to imports of certain pigmeat products originating in the African, Caribbean and Pacific States (ACP) or in the overseas countries and territories (OCT), OJ L 93/23, 10 April 1990

1740/90 Commission Regulation of 26 June 1990 amending Regulation 904/90 laying down detailed rules for the application of the arrangements applicable to imports of certain pigmeat products originating in the African, Caribbean and Pacific States (ACP) or in the overseas countries and territories (OCT), OJ L 161/30, 27 June 1990

1741/90 Commission Regulation of 26 June 1990 amending Regulation 903/90 laying down detailed rules for the application of the arrangements applicable to imports of certain poultrymeat products originating in the African, Caribbean and Pacific States (ACP) or in the overseas countries and territories (OCT), OJ L 161/32, 27 June 1990

1842/90 Commission Regulation of 29 June 1990 amending Regulation 1156/90 on import licenses for poultrymeat products originating in the African, Caribbean and Pacific States (ACP States) or in the overseas countries and territories (OCT), OJ L 168/15, 30 June 1990

1843/90 Commission Regulation of 29 June 1990 amending Regulation 1155/90 on import licenses for pigmeat products originating in the African, Caribbean and Pacific States (ACP States) or in the overseas countries and territories (OCT), OJ L 168/16, 30 June 1990 
970/90 Commission Regulation of 18 April 1990 laying down detailed rules for the application in the beef and veal sector of Council Regulation 715/90 on the arrangements applicable to agricultural products and certain goods resulting from the processing of agricultural products originating in the African, Caribbean and Pacific States or in the overseas countries and territories and amending Regulation 2377/80, OJ L 99/8, 19 April 1990

999/90 Commission Regulation of 20 April 1990 laying down detailed implementing rules for imports of rice originating in the African, Caribbean and Pacific States (ACP), and the overseas countries and territories (OCT), OJ L 101/20, 21 April 1990

1150/90 Commission Regulation of 4 May 1990 laying down detailed rules for the application of the arrangements applicable to imports of certain milk products originating in the African, Caribbean and Pacific States (ACP States) or in the overseas countries and territories (OCT), OJ L 114/21, 5 May 1990

2975/90 Commission Regulation of 15 October 1990 amending Regulation 1150/90 laying down detailed rules for the application of the arrangements applicable to imports of certain milk products originating in the African, Caribbean and Pacific States (ACP States) or in the overseas countries and territories (OCT), OJ L 283/16, 16 October 1990

1389/90 Commission Regulation of 23 May 1990 providing for the administration of a Community quota for molasses originating in the African, Caribbean and Pacific States (ACP States) or in the overseas countries and territories (OCT), OJ L 133/41, 24 May 1990

$1597 / 90$ Commission Regulation of 14 June 1990 on the arrangement applicable to agricultural products subject to reference quantities and originating in the African, Caribbean and Pacific States or in the overseas countries and territories (1990/91), OJ L 151/26, 15 June 1990

1664/90 Commission Regulation of 20 June 1990 opening and providing for the administration of Community tariff quotas for certain agricultural products originating in the African, Caribbean and Pacific States or in the overseas countries and territories (1990/91), OJ L 155/22, 21 June 1990

1799/90 Council Regulation of 27 June 1990 opening, allocating and providing for the administration of a Community tariff quota for rum, tafia and arrack originating in the African, Caribbean and Pacific (ACP) States (1990/91), OJ L 167/3, 30 June 1990

1800/90 Council Regulation of 27 June 1990 opening, allocating and providing for the administration of a Community tariff quota for rum, tafia and arrack originating in the overseas countries and territories (OCT) associated with the European Economic Community (1990/91), OJ L 167/6, 30 June 1990

1929/90 Council Regulation of 29 June 1990 derogating from the definition of the concept of 'originating products' to take account of the special situation of the Netherlands Antilles with regard to chemical-proof overalls falling with $\mathrm{CN}$ code 62101099 , OJ L 174/5, 7 July 1990

2209/90 Council Regulation of 27 July 1990 derogating from the definition of 'originating products' to take account of the special situation of Saint-Pierre and Miquelon with regard to certain fisheries products, OJ L 202/1, 31 July 1990 
2245/90 Commission Regulation 2245/90 of 31 July 1990 laying down detailed rules for the application of the import arrangements applicable to products falling within CN codes 07141091 and 07149011 and originating in the African, Caribbean and Pacific (ACP) States or in the overseas countries and territories (OCT), OJ L 203/47, 1 August 1990

2913/90 Council Regulation of 8 October 1990 derogating from the definition of the concept of 'originating products' to take account of the special situation of the Netherlands' Antilles with regard to cigarettes falling within CN code 240220 00, OJ L 279/1, 11 October 1990

3231/90 Council Regulation of 5 November 1990 establishing Community supervision for the imports of certain agricultural products originating in the Canary Islands (1991), OJ L 310/6, 9 November 1990

3414/90 Council Regulation of 20 November 1990 opening and providing for the administration of Community tariff quotas for some products originating in the Canary Islands (1991), OJ L 330/1, 29 November 1990

3734/90 Council Regulation of 14 December 1990 opening tariff quotas for the importation into that part of Spain included in the customs territory of the Community, of certain fisheries products originating in the Canary Islands or Ceuta and Melilla (1991), OJ L 363/28, 27 December 1990

3735/90 Council Regulation of 14 December 1990 opening and providing for the administration of Community tariff quotas for certain fisheries products originating in the Canary Islands (1991), OJ L 363/39, 27 December 1990

3598/90 Commission Regulation of 13 December 1990 on the arrangements applicable to agricultural products subject to reference quantities and originating in the African, Carribean and Pacific States or in the overseas countries and territories (1991), OJ L 350/47, 14 December 1990

\section{General Acts Pertaining to Associated Countries and Territories}

90/146 Council Decision of 5 March 1990 amending Dec. 86/283/EEC on the association of the overseas countries and territories (OCT) with the European Economic Community, OJ L 84/108, 30 March 1990

90/523 Council Decision of 8 October 1990 on the procedure conceming derogations from the rules of origin set out in Protocol No. 1 to the Fourth ACP-EEC Convention, OJ L 290/33, 23 October 1990

3705/90 Council Regulation of 18 December 1990 on the safeguard measures provided for in the Fourth ACP-EEC Convention, OJ L 358/4, 21 December 1990

90/669 Council Decision of 20 December 1990 renewing the arrangements for trade between Spain and Portugal on the one hand and the overseas countries and territories (OCT) on the other, OJ L 365/79, 28 December 1990

$90 / 670$ Decision of the representatives of the Governments of the Member States, meeting within the Council, of 20 December 1990 amending Decision 86/50 establishing arrangements for trade between Spain and Portugal on the one hand and the overseas countries and territories (OCT) on the other in products covered by the ECSC Treaty 


\section{Agreements with Associated Countries and Unilateral Modifications of the Special Trade Regimes with these Countries}

\section{Multilateral Agreements and Unilateral Acts Referring to Several Countries}

728/90 Council Regulation of 22 March 1990 opening and providing for the administration of Community tariff quotas for cut flowers and flower buds, fresh, originating in Cyprus, Israel, Jordan or Morocco (1990/91), OJ L 81/7, 28 March 1990

1275/90 Council Regulation of 7 May 1990 opening and providing for the administration of Community tariff quotas for certain agricultural products originating in Cyprus, Morocco and Israel (1990), OJ L 126/6, 16 May 1990

Corrigendum to Council Regulation $1275 / 90$ of 7 May 1990 opening and providing for the administration of Community tariff quotas for certain agricultural products originating in Cyprus, Morocco and Israel (1990) (OJ L 126 of 16 May 1990), OJ L 223/23, 18 August 1990

1387/90 Commission Regulation of 23 May 1990 fixing Community producer prices for carnations and roses for the application of the import arrangements for certain floricultural products originating in Cyprus, Israel, Jordan and Morocco, OJ L 133/37, 24 May 1990

2876/90 Commission Regulation of 4 October 1990 extending Regulation 2985/89 introducing retrospective Community surveillance of imports of certain textile products originating in Tunisia or Morocco, OJ L 275/34, 5 October 1990

$3129 / 90$ Commission Regulation of 29 October 1990 fixing Community producer prices for carnations and roses for the application of the import arrangements for certain floricultural products originating in Cyprus, Israel, Jordan and Morocco, OJ 1990, L 299/26, 30 October 1990

$3729 / 90$ Council Regulation of 13 December 1990 opening and providing for the administration of Community tariff quotas for certain agricultural products originating in Algeria, Morocco, Tunisia and Egypt (1991), OJ L 363/1, 27 December 1990

3732/90 Council Regulation of 13 December 1990 establishing Community statistical surveillance for certain agricultural products originating in Cyprus, Yugoslavia, Egypt, Jordan, Israel, Tunisia, Syria, Malta and Morocco which are subject to reference quantities (1991), OJ L 363/18, 27 December 1990

$3797 / 90$ Commission Regulation of 21 December 1990 on protective measures applicable to imports of certain semi-processed red fruits originating in Poland and Yugoslavia, OJ L 365/22, 28 December 1990

\section{Bilateral Agreements and Unilateral Acts Referring to Single Countries}

Cyprus

Information concerning the date of entry into force of the Protocol on financial and technical cooperation between the European Economic Community and the Republic of Cyprus signed in Brussels on 30 November 1989, OJ L 107/67, 27 April 1990 
49/90 Commission Regulation of 10 January 1990 amending Regulation 1767/82 as regards imports of certain cheeses from Cyprus, OJ L 8/18, 11 January 1990

90/153 Council Decision of 26 February 1990 on the conclusion of a protocol on financial and technical cooperation between the European Economic Community and the Republic of Cyprus, OJ L 82/32, 29 March 1990

Protocol on financial and technical cooperation between the European Economic Community and the Republic of Cyprus, OJ L 82/33, 29 March 1990

2031/90 Commission Regulation of 17 July 1990 on the adjustment of the entry price for table grapes originating in Cyprus, OJ L 186/9, 18 July 1990

3202/90 Council Reg of 22 October 1990 on the application of Decision 3/90 of the EEC-Cyprus Association Council amending, on account of the accession of the Kingdom of Spain and the Portuguese Republic to the Community, the Protocol concerning the definition of the concept of 'originating products' and methods of administrative cooperation, OJ L 307/1, 7 November 1990

Decision 3/90 of the EEC-Cyprus association Council of 22 October 1990 amending, on account of the accession of the Kingdom of Spain and the Portuguese Republic to the Community, the Protocol conceming the definition of the concept of 'originating products' and methods of administrative cooperation, OJ L 307/2, 7 November 1990

3203/90 Council Regulation of 22 October 1990 on the application of Decision 4/90 of the EEC-Cyprus Association Council again amending Articles 6 and 17 of the Protocol concerning the definition of the concept of 'originating products' and methods of administrative cooperation, OJ L 307/4, 7 November 1990

Decision 4/90 of the Association Council of 22 October 1990 again amending Articles 6 and 17 of the Protocol concerning the definition of the concept of 'originating products' and methods of administrative cooperation, OJ L $307 / 5$, 7 November 1990

$3347 / 90$ Council Regulation of 19 November 1990 opening and providing for the administration of Community tariff quotas for certain agricultural products originating in Cyprus (1991), OJ L 324/3, 23 November 1990

\section{Egypt}

3069/90 Council Regulation of 22 October 1990 again amending Articles 6 and 17 of the Protocol concerning the concept of 'originating products' and methods of administrative cooperation to the Cooperation Agreement between the European Economic Community and the Arab Republic of Egypt, OJ L 295/2, 26 October 1990

Israel

3730/90 Council Regulation of 13 December 1990 opening and providing for the administration of Community tariff quotas for certain agricultural products originating in Israel (1991), OJ L 363/10, 27 December 1990 
The Treaty Practice of the European Communities in 1990

Jordan

$3070 / 90$ Council Regulation of 22 October 1990 again amending Articles 6 and 17 of the Protocol concerning the concept of 'originating products' and methods of administrative cooperation to the Cooperation Agreement between the European Economic Community and the Hashemite Kingdom of Jordan, OJ L 295/3, 26 October 1990

\section{Lebanon}

$3071 / 90$ Council Regulation of 22 October 1990 again amending Articles 6 and 17 of the Protocol concerning the concept of 'originating products' and methods of administrative cooperation to the Cooperation Agreement between the European Economic Community and the Lebanese Republic, OJ L 295/4, 26 October 1990

\section{Malta}

2174/90 Council Regulation of 23 July 1990 on the application of Decision No. 1/90 of the EEC-Malta Association Council amending, on account of the accession of the Kingdom of Spain and the Portuguese Republic to the Community, the Protocol concerning the definition of the concept of 'originating products' and methods of administrative cooperation, OJ L 198/1, 28 July 1990

Decision No. 1/90 of the EEC-Malta Association Council of 16 July 1990 amending, on account of the accession of the Kingdom of Spain and the Portuguese Republic to the Community, the Protocol concerning the definition of the concept of 'originating products' and methods of administrative cooperation, OJ L 198/2, 28 July 1990

2175/90 Council Regulation of 23 July 1990 on the application of Decision No. 2/90 of the EEC-Malta Association Council again amending Articles 6 and 17 of the Protocol concerning the definition of the concept of 'originating products' and methods of administrative cooperation, OJ L 198/4, 28 July 1990

Decision No. 2/90 of the EEC-Malta Association Council of 16 July 1990 again amending Articles 6 and 17 of the Protocol concerning the definition of the concept of 'originating products' and methods of administrative cooperation, OJ L 198/5, 28 July 1990

3346/90 Council Regulation of 19 November 1990 opening and providing for the administration of a Community tariff quota for beer made from malt originating in Malta (1991), OJ L 324/1, 23 November 1990

3704/90 Council Regulation of 18 December 1990 extending the arrangements applicable to trade with Malta beyond the expiry date of the first stage of the Association Agreement, OJ L 358/3, 21 December 1990

3733/90 Council Regulation of 13 December 1990 establishing ceilings and Community surveillance for imports of certain products originating in Malta (1991), OJ L 363/21, 27 December 1990 
Frank Emmert

Morocco

727/90 Council Regulation of 22 March 1990 opening and providing for the administration of a Community tariff quota for certain wines having a registered designation of origin and originating in Morocco (1990/91), OJ L 81/3, 28 March 1990

90/408 Council Decision of 27 July 1990 on the conclusion of the Agreement in the form of an Exchange of Letters concerning the provisional application of Protocol 2 establishing for the period 1 April 1990 to 31 March 1991 the crawfish fishing opportunities and the corresponding financial compensation provided for in the Agreement on relations in the sea fisheries sector between the European Economic Community and the Kingdom of Morocco, OJ L 208/39, 7 August 1990

Corrigendum to Council Decision $90 / 408$ of 27 July 1990 on the conclusion of the Agreement in the form of an exchange of letters concerning the provisional application of Protocol No. 2 establishing for the period 1 April 1990 to 31 march 1991 the crawfish opportunities and the corresponding financial compensation provided for in the Agreement on relations in the sea fisheries sector between the European Economic Community and the Kingdom of Morocco (OJ L 208), OJ L 333/66, 30 November 1990

Agreement in the form of an Exchange of Letters conceming the provisional application of Protocol 2 establishing for the period from 1 April 1990 to 31 March 1991 the crawfish fishing opportunities and corresponding financial compensation provided for in the Agreement on relations in the sea fisheries sector between the European Economic Community and the Government of the Kingdom of Morocco, OJ L 208/40, 7 August 1990

3072/90 Council Regulation of 22 October 1990 again amending Articles 6 and 17 of the Protocol concerning the concept of 'originating products' and methods of administrative cooperation to the Cooperation Agreement between the European Economic Community and the Kingdom of Morocco, OJ L 295/5, 26 October 1990

3731/90 Council Regulation of 13 December 1990 opening, allocating and providing for the administration of a Community tariff quota for prepared or preserved sardines, originating in Morocco (1991), OJ L 363/15, 27 December 1990

Turkey

726/90 Council Regulation of 22 March 1990 opening and providing for the administration of a Community tariff quota for apricot pulp originating in Turkey (1990/91), OJ L 81/1, 28 March 1990

90/445 Commission Decision of 26 July 1990 concerning animal health conditions and veterinary certification for the importation of fresh meat from Turkey, OJ L 228/28, 22 August 1990

3348/90 Council Regulation of 19 November 1990 opening and providing for the administration of a Community tariff quota for fresh or dried hazelnuts, shelled or not, originating in Turkey (1991), OJ L 324/8, 23 November 1990

$3630 / 90$ Commission Regulation of 14 December 1990 reimposing the levying of customs duties applicable to third countries on certain products originating in Turkey, OJ L 355/5, 18 December 1990 
Yugoslavia

708/90 Commission Regulation of 22 March 1990 concerning Annex VII to Council Regulation 4135/86 relating to specific quantitative limits on the importation into Italy under outward processing relief arrangements of certain textile products (categories 6, 7 and 15) originating in Yugoslavia for 1990, OJ L 78/10, 24 March 1990

$889 / 90$ Commission Regulation of 6 April 1990 reimposing the levying of customs duties applicable to third countries on certain products originating in Yugoslavia, OJ L 92/29, 7 April 1990

* Agreement in the form of an Exchange of Letters relating to the 1981 Agreement between the European Economic Community and the Socialist Federal Republic of Yugoslavia on trade in the sheepmeat and goatmeat sector, OJ L 95/25, 12 April 1990

997/90 Commission Regulation of 20 April 1990 reimposing the levying of customs duties applicable to third countries on certain products originating in Yugoslavia, OJ L 101/9, 21 April 1990

$1148 / 90$ Commission Regulation $1148 / 90$ of 4 May 1990 reimposing the levying of customs duties applicable to third countries on certain products originating in Yugoslavia, OJ L 114, 5 May 1990

1280/90 Commission Regulation of 15 May 1990 reimposing the levying of customs duties applicable to third countries on certain products originating in Yugoslavia, OJ L 126/22, 16 May 1990

1428/90 Commission Regulation of 29 May 1990 reimposing the levying of customs duties applicable to third countries on certain products originating in Yugoslavia, OJ L 137/20, 30 May 1990

1632/90 Commission Regulation of 15 June 1990 re-establishing the levying of customs duties applicable to third countries on certain products originating in Yugoslavia, OJ L 153/8, 19 June 1990

$1645 / 90$ Commission Regulation of 18 June 1990 on the opening of supplementary quotas for imports into the Community of certain textile products originating in Yugoslavia for the 1990 Berlin Trade Fairs, OJ L 154/15, 20 June 1990

1656/90 Council Regulation of 18 June 1990 amending Regulation 1200/88 establishing a surveillance mechanism for imports of sour cherries, fresh, originating in Yugoslavia, OJ L 155/5, 21 June 1990

1663/90 Commission Regulation of 20 June 1990 amending Regulation 1385/88 laying down special detailed rules for the application of the system of import licenses for fresh sour cherries originating in Yugoslavia, OJ L 155/20, 21 June 1990

1706/90 Commission Regulation of 22 June 1990 amending Regulation 16/90 on the issuing and suspension of import licenses for certain processed products obtained from sour cherries originating in Yugoslavia, OJ L 158/33, 23 June 1990

1753/90 Commission Regulation of 27 June 1990 re-establishing the levying of customs duties applicable to third countries on certain products originating in Yugoslavia, OJ L 162/14, 28 June 1990 
1965/90 Commission Regulation of 10 July 1990 reimposing the levying of customs duties applicable to third countries on certain products originating in Yugoslavia, OJ L 178/8, 11 July 1990

1966/90 Commission Regulation of 10 July 1990 repealing Regulation 1428/90 reimposing the levying of customs duties applicable to third countries on certain products originating in Yugoslavia, OJ L 178/12, 11 July 1990

2045/90 Commission Regulation of 18 July 1990 reimposing the levying of customs duties applicable to third countries on certain products originating in Yugoslavia, OJ L 187/21, 19 July 1990

2199/90 Commission Regulation of 27 July 1990 on protective measures applicable to imports of frozen raspberries and provisionally preserved raspberries originating in Yugoslavia, OJ L 198/55, 28 July 1990

2285/90 Commission Regulation of 2 August 1990 re-establishing the levying of customs duties applicable to third countries on certain products originating in Yugoslavia, Of L 205/19, 3 August 1990

2396/90 Commission Regulation of 16 August 1990 re-establishing the levying of customs duties applicable to third countries on certain products originating in Yugoslavia, OJ L 222/32, 17 August 1990

2781/90 Council Regulation of 24 September 1990 amending Regulation 1201/88 establishing import mechanisms for certain processed products obtained from sour cherries and originating in Yugoslavia, OJ L 265/3, 28 September 1990

2836/90 Commission Regulation of 26 September 1990 reimposing the levying of customs duties applicable to third countries on certain products originating in Yugoslavia, OJ L 268/90, 29 September 1990

3045/90 Commission Regulation of 23 October 1990 reimposing the levying of customs duties applicable to third countries on certain products originating in Yugoslavia, OJ L 292/8, 24 October 1990

3059/90 Commission Regulation of 24 October 1990 amending the quantitative limits fixed by Council Regulation 4135/86 on rules for imports of certain textile products originating in Yugoslavia, OJ L 294/20, 25 October 1990

3073/90 Council Regulation of 22 October 1990 again amending Articles 6 and 17 of the Protocol concerning the concept of 'originating products' and methods of administrative cooperation to the Cooperation Agreement between the European Economic Community and the Socialist Federal Republic of Yugoslavia, OJ L 295/6, 26 October 1990

3343/90 Commission Regulation of 20 November 1990 re-establishing the levying of customs duties applicable to third countries on certain products originating in Yugoslavia, OJ L 323/12, 22 November 1990

3412/90 Council Regulation of 19 November 1990 establishing ceilings and Community surveillance for imports of certain products originating in Yugoslavia (1991), OJ L 335/1, 30 November 1990

3413/90 Council Regulation of 19 November 1990 opening and providing for the administration of Community tariff quotas for certain products originating in Yugoslavia (1991), OJ L 335/26, 30 November 1990 
$3477 / 90$ Commission Regulation of 30 November 1990 re-establishing the levying of customs duties applicable to third countries on certain products originating in Yugoslavia, OJ L 336/64, 1 December 1990

90/649 Council Decision of 24 September 1990 concerning the conclusion of a supplementary Protocol to the Cooperation Agreement between the European Economic Community and the Socialist Federal Republic of Yugoslavia on trade in textile products, OJ L 352/120, 15 December 1990

Supplementary Protocol to the Cooperation Agreement between the European Economic Community and the Socialist Federal Republic of Yugoslavia on trade in textile products, OJ L 352/121, 15 December 1990

$3717 / 90$ Commission Regulation of 19 December 1990 amending Regulation 4061/88 laying down further detailed rules of application as regards import licenses for certain processed products obtained from sour cherries originating in Yugoslavia, OJ L 358/49, 21 December 1990

3652/90 Council Regulation of 11 December 1990 amending Regulation 1200/88 establishing a surveillance mechanism for imports of sour cherries, fresh, originating in Yugoslavia, OJ L 362/27, 27 December 1990

\section{Agreements with State-Trading Countries Other than Modifications of the CCT and the Customs Regime and Unilateral Acts Referring to these Countries}

\section{Bulgaria}

90/519 Council Decision of 24 September 1990 on the conclusion of an Agreement between the European Economic Community and the People's Republic of Bulgaria on trade and commercial and economic cooperation, OJ L 291/8, 23 October 1990

Agreement between the European Economic Community and the People's Republic of Bulgaria on trade and commercial and economic cooperation, OJ L 291/9, 23 October 1990

Agreement in the form of an Exchange of Letters between the European Economic Community and the People's Republic of Bulgaria concerning 'Testausschreibung', OJ L 291/23, 23 October 1990

Final Act, OJ L 291/25, 23 October 1990

Information concerning the date of entry into force of the Agreement between the European Economic Community and the People's Republic of Bulgaria on trade and commercial and economic cooperation, OJ L 291/43, 23 October 1990

\section{Czech and Slovak Federal Republic}

90/520 Council Decision of 24 September 1990 on the conclusion, on behalf of the European Economic Community, of an Agreement between the European Economic Community and the European Atomic Energy Community and the 
Czech and Slovak Federal Republic on trade and commercial and economic cooperation, OJ L 291/28, 23 October 1990

Agreement between the European Economic Community and the European Atomic Energy Community and the Czech and Slovak Federal Republic on trade and commercial and economic cooperation, OJ L 291/29, 23 October 1990

Information on the date of entry into force of the Agreement between the European Economic Community and the European Atomic Energy Community and the Czech and Slovak Federal Republic on trade and commercial and economic cooperation, OJ L 291/43, 23 October 1990

90/521 Commission Decision of 27 September 1990 concerning the conclusion on behalf of the European Atomic Energy Community of the Agreement between the European Economic Community and the European Atomic Energy Community and the Czech and Slovak Federal Republic on trade and commercial and economic cooperation, OJ L 291/44, 23 October 1990

\section{Hungary}

90/83 Council Decision of 22 February 1990 providing medium-term financial assistance for Hungary, OJ L 58/7, 7 March 1990

90/509 Council Decision of 24 September 1990 concerning the provisional application of the Agreed Minute amending the Agreement between the European Economic Community and the Republic of Hungary on trade in textile products, OJ L 285/26, 17 October 1990

Agreed Minute, OJ L 285/27, 17 October 1990

\section{Poland}

457/90 Council Regulation of 22 February 1990 on emergency action of the supply of certain agricultural products to Poland, OJ L 48/3, 24 February 1990

90/115 Council Decision of 12 February 1990 on the conclusion of an Agreement in the form of an an exchange of letters suspending the application of Article 12 (1) of the Agreement between the European Economic Community and the Polish People's Republic on trade and commercial and economic cooperation, OJ L 69/69, 16 March 1990

Agreement in the form of an an exchange of letters suspending the application of Article 12 (1) of the Agreement between the European Economic Community and the Polish People's Republic on trade and commercial and economic cooperation, OJ L 70/69, 16 March 1990

2198/90 Commission Regulation of 27 July 1990 on protective measures applicable to imports of frozen strawberries, frozen raspberries, provisionally preserved strawberries and provisionally preserved raspberries originating in Poland, OJ L 198/53, 28 July 1990

90/508 Council Decision of 24 September 1990 concerning the provisional application of the Agreed Minute amending the Agreement between the European Economic Community and the Republic of Poland on trade in textile products, OJ L 285/22, 17 October 1990

Agreed Minute, OJ L 285/23, 17 October 1990 


\section{Romania}

282/90 Council Regulation of 23 January 1990 on emergency action for the supply of certain agricultural products to Romania, OJ L 31/1, 2 February 1990

454/90 Commission Regulation of 22 February 1990 laying down detailed rules for an emergency supply of cereals, beef and butter to Romania, OJ L 47/21, 23 February 1990

456/90 Council Regulation of 22 February 1990 on a second emergency action for the supply of certain agricultural products to Romania, OJ L 48/1, 24 February 1990

969/90 Commission Regulation of 18 April 1990 laying down detailed rules for a second emergency supply of cereals, beef and butter to Romania, OJ L 99/5, 19 April 1990

\section{Union of Soviet Socialist Republics}

90/116 Council Decision of 26 February 1990 on the conclusion by the European Economic Community of an Agreement between the European Economic Community and the European Atomic Energy Community and the Union of Soviet Socialist Republics on trade and commercial and economic cooperation, OJ L 68/1, 15 March 1990

90/117 Commission Decision of 27 February 1990 on the conclusion on behalf of the European Atomic Energy Community of the Agreement between the European Economic Community and the European Atomic Energy Community and the Union of Soviet Socialist Republics on trade and commercial and economic cooperation, OJ L 68/2, 15 March 1990

Agreement between the European Economic Community and the European Atomic Energy Community and the Union of Soviet Socialist Republics on trade and commercial and economic cooperation, OJ L 68/3, 15 March 1990

Agreement in the form of an exchange of letters between the European Economic Community and the Union of Soviet Socialist Republics concerning 'Testausschreibung', OJ L 68/18, 15 March 1990

Information on the date of entry into force of the Agreement between the European Economic Community and the European Atomic Energy Community, on the one hand, and the Union of Soviet Socialist Republics, on the other hand, on trade and commercial and economic cooperation, OJ L 68/20, 15 March 1990

1434/90 Council Regulation of 14 May 1990 implementing certain provisions of the Agreement between the European Economic Community and the European Atomic Energy Community and the Union of the Soviet Socialist Republics on trade and commercial and economic cooperation, OJ L 138/1, 31 May 1990

\section{State-Trading Countries in General}

90/397 Decision of the representatives of the Governments of the Member States meeting within the Council of 29 June 1990 on certain measures to be applied, in 
respect of State-trading countries, to trade in iron and steel products covered by the ECSC Treaty, OJ L 199/13, 30 July 1990

2698/90 Council Regulation of 17 September 1990 amending Regulation 3906/89 in order to extend economic aid to other countries of Central and Eastern Europe, OJ L 257/1, 21 September 1990

2727/90 Council Regulation of 25 September 1990 liberalizing or suspending quantitative restrictions applying to certain countries of Central and Eastern Europe and amending Regulation 3420/83 and 288/82 accordingly, OJ L 262/11, 26 September 1990

Corrigendum to Council Regulation $2727 / 90$ of 25 September 1990 liberalizing or suspending quantitative restrictions applying to certain countries of Central and Eastern Europe and amending Regulation 3420/83 and 288/82 accordingly (OJ L 262 of 26 September 1990) OJ L 295/74, 26 October 1990

90/468 Council Decision of 27 July 1990 on import quotas to be opened by Member States in respect of State-trading countries in 1990, OJ L 259/1, 24 September 1990

\section{Multilateral Conventions and Agreements with NGOs}

90/69 Council Decision of 18 December 1989 concerning the conclusion of the Protocol for the accession of Bolivia to the General Agreement on Tariffs and Trade, OJ L 45/24, 21 February 1990

Protocol for the accession of Bolivia to the General Agreement on Tariffs and Trade, OJ L 45/25, 21 February 1990

Information concerning the signature of the Protocol for the accession of Bolivia to the General Agreement on Tariffs and Trade, OJ L 45/27, 21 February 1990

90/416 Council Decision of 23 April 1990 concerning the conclusion of the Protocol for the Accession of Costa Rica to the General Agreement on Tariffs and Trade, OJ L 219/58, 14 August 1990

Protocol for the accession of Costa Rica to the General Agreement on Tariffs and Trade, OJ L 219/59, 14 August 1990

Information concerning the signing of the Protocol of Accession of Costa Rica to the General Agreement on Tariffs and Trade, OJ L 219/61, 14 August 1990

90/491 Council Decision of 27 July 1990 concerning the conclusion of the Protocol for the Accession of Tunisia to the General Agreement on Tariffs and Trade, OJ 1990, L 274/17, 4 October 1990

Protocol for the accession of Tunisia to the General Agreement on Tariffs and Trade, OJ L 274/18, 4 October 1990

Information concerning the signing of the Protocol of Accession of Tunisia to the General Agreement on Tariffs and Trade, OJ L 274/29, 4 October 1990

197/90 Commission Regulation of 17 January 1990 amending Council Regulation $3626 / 82$ on the implementation in the Community of the Convention on international trade in endangered species of wild fauna and flora, OJ L 29/1, 31 January 1990 
90/222 Council Decision of 23 April 1990 on the conclusion of the Convention between the European Economic Community and the United Nations Relief and Works Agency for Palestine Refugees (UNRWA) concerning aid to refugees in the countries of the Near East, OJ L 118/36, 9 May 1990

Convention between the European Economic Community and the United Nations Relief and Works Agency for Palestine Refugees (UNRWA) concerning aid to refugees in the countries of the Near East, OJ L 118/37, 9 May 1990

1599/90 Commission Regulation of 14 June 1990 amending Regulation 3154/85 and $3719 / 88$ with a view to facilitating certain private humanitarian aid operations for the benefit of people in third countries, OJ L 151/29, 15 June 1990

1930/90 Council Regulation of 29 June 1990 amending Regulation 3972/86 on food-aid policy and food-aid management, Regulation $2507 / 88$ on the implementation of storage programmes and early warning systems and Regulation 2508/88 on the implementation of co-financing operations for the purchase of food products or seeds by international bodies or non-governmental organizations, OJ L 174/6, 7 July 1990

90/500 Commission Decision of 2 October 1990 amending Decision 86/77 approving certain food-aid operations carried out by humanitarian organizations and exempting them from monetary compensatory amounts, OJ L 278/40, 10 October 1990

90/611 Council Decision of 22 October 1990 concerning the conclusion, on behalf of the European Economic Community, of the United Nations Convention against Illicit Traffic in Narcotic Drugs and Psychtropic Substances, OJ L 326/56, 24 November 1990

\section{Agreements with Countries not Enjoying General Preferential Status and Unilateral Modifications of the EC Customs Regime}

\section{General Agreements}

90/37 Council Decision of 22. January 1990 authorizing extension or tacit renewal of certain trade agreements concluded between Member States and third countries, OJ L 21/67, 26 January 1990

90/61 Council Decision of 12 February 1990 authorizing the automatic renewal or maintenance in force of provisions goveming matters covered by the common commercial policy contained in the friendship, trade and navigation treaties and similar agreements concluded between Member States and third countries, OJ L 42/59, 16 February 1990

90/225 Council Decision of 7 May 1990 authorizing extension or tacit renewal of certain trade agreements concluded between Member States and third countries, Of L 120/72, 11 May 1990

90/235 Council Decision of 21 May 1990 authorizing extension or tacit renewal of certain trade agreements concluded between Member States and third countries, OJ L 133/85, 24 May 1990

90/530 Council Decision of 8 October 1990 concerning the conclusion of the Framework Agreement for trade and economic cooperation between the 
European Economic Community and the Argentine Republic, Of L 295/66, 26 October 1990

Framework Agreement for trade and economic cooperation between the European Economic Community and the Argentine Republic, OJ L 295/67, 26 October 1990

Exchange of Letters, OJ L 295/66, 26 October 1990

\section{Agreements and Unilateral Acts Concerning Textlle Products and Footwear}

90/174 Council Decision of 12 March 1990 concerning the provisional application of the Agreed Minute modifying the Agreement between the European Economic Community and Hong Kong on trade in textile products, OJ L 96/84, 12 April 1990

Agreed Minute, OJ L 96/85, 12 April 1990

Information concerning the modification of the Agreement between the Community and Hong Kong on trade in textile products, OJ L 96/86, 12 April 1990

90/175 Council Decision of 2 April 1990 concerning the provisional application of the Agreed Minute amending the Agreement between the European Economic Community and the People's Republic of China on trade in textile products, OJ L 96/87, 12 April 1990

Agreed Minute, OJ L 96/88, 12 April 1990

Information concerning the amendment of the Agreement between the Community and China on trade in textile products, Of L 96/91, 12 April 1990

90/647 Council Decision of 24 September 1990 concerning the conclusion of the Agreement between the European Economic Community and the People's Republic of China on trade in textile products, OJ L 352/1, 15 December 1990

Agreement between the European Economic Community and the People's Republic of China on trade in textile products, OJ L 352/2, 15 December 1990

90/503 Council Decision of 8 October 1990 concerning the provisional application of the Agreed Minute amending the Agreement between the European Economic Community and the Democratic Socialist Republic of Sri Lanka on trade in textile products, OJ L 281/26, 12 October 1990

Agreed Minute, OJ L 281/27, 12 October 1990

90/537 Council Decision of 27 July 1990 concerning the conclusion to the Agreement between the European Economic Community and the Democratic Socialist Republic of Sri Lanka on trade in textile products, OJ L 301/1, 30 October 1990

Agreement between the European Economic Community and the Democratic Socialist Republic of Sri Lanka on trade in textile products, OJ L 301/2, 30 October 1990

90/538 Council Decision of 27 July 1990 concerning the conclusion of the Agreement between the European Economic Community and the Republic of India on trade in textile products, OJ L 301/46, 30 October 1990 
Agreement between the European Economic Community and the Republic of India on trade in textile products, OJ L 301/47. 30 October 1990

90/607 Council Decision of 27 July 1990 concerning the conclusion of the Agreement between the European Economic Community and the People's Republic of Bangladesh on trade in textile products, OJ 1991 L 325/1, 23 November 1990

Agreement between the European Economic Community and the People's Republic of Bangladesh on trade in textile products, OJ $1991 \mathrm{~L} \mathrm{325/2,23}$ November 1990

90/608 Council Decision of 27 July 1990 concerning the conclusion of the Agreement between the European Economic Community and the Kingdom of Thailand on trade in textile products, OJ L 325/40, 23 November 1990

Agreement between the European Economic Community and the Kingdom of Thailand on trade in textile products, OJ L 325/41, 23 November 1990

90/616 Council Decision of 27 July 1990 concerning the conclusion of the Agreement between the European Economic Community and the Republic of Singapore on trade in textile products, OJ L 329/1, 28 November 1990

Agreement between the European Economic Community and the Republic of Singapore on trade in textile products, OJ L 329/2, 28 November 1990

90/617 Council Decision of 27 July 1990 concerning the conclusion of the Agreement between the European Economic Community and the Republic of Indonesia on trade in textile products, OJ L 329/42, 28 November 1990

Agreement between the European Economic Community and the Republic of Indonesia on trade in textile products, OJ L 329/43, 28 November 1990

90/624 Council Decision of 27 July 1990 concerning the conclusion of the Agreement between the European Economic Community and the Republic of the Philippines on trade in textile products, OJ L 339/1, 5 December 1990

Agreement between the European Economic Community and the Republic of the Philippines on trade in textile products, OJ L 339/2, 5 December 1990

90/625 Council Decision of 27 July 1990 concerning the conclusion of the Agreement between the European Economic Community and Malaysia on trade in textile products, OJ L 339/42, 5 December 1990

Agreement between the European Economic Community and Malaysia on trade in textile products, OJ L 339/43, 5 December 1990

90/648 Council Decision of 24 September 1990 concerning the conclusion of the Agreement between the European Economic Community and the Islamic Republic of Pakistan on trade in textile products, OJ L 352/74, 15 December 1990

Agreement between the European Economic Community and the Islamic Republic of Pakistan on trade in textile products, OJ L 352/75, 15 December 1990

274/90 Commission Regulation of 31 January 1990 introducing retrospective Community surveillance of imports into the Community of footwear originating in all non-member countries, OJ L 30/54, 1 February 1990

842/90 Commission Regulation of 30 March 1990 reintroducing the levying of the customs duties on men's or boy's suits and ensembles, products of category 
No. 16 (order No. 40.0160) and women's or girl's suits and ensembles products of category No. 74 (order No. 40.0740) originating in Thailand, to which the preferential tariff arrangements set out in Council Regulation 3897/89 apply, OJ L 88/23, 3 April 1990

843/90 Commission Regulation of 30 March 1990 reintroducing the levying of the customs duties on women's or girl's dresses, products of category No. 26 (order No. 40.0260) and women's or girl's suits and ensembles products of category No. 29 (order No. 40.0290) originating in Pakistan, to which the preferential tariff arrangements set out in Council Regulation 3897/89 apply, OJ L 88/25, 3 April 1990

844/90 Commission Regulation of 30 March 1990 reintroducing the levying of the customs duties on women's or girl's suits and ensembles, products of category No. 74 (order No. 40.0740) and garments products of category No. 78 (order No. 40.0780) originating in India, to which the preferential tariff arrangements set out in Council Regulation 3897/89 apply, OJ L 88/27, 3 April 1990

845/90 Commission Regulation of 2 April 1990 reintroducing the levying of the customs duties on footwear falling within CN codes 6401 and 6402 originating in China to which the preferential tariff arrangements set out in Council Regulation 3896/89 apply, OJ L 88/29, 3 April 1990

Corrigendum to Commission Regulation 845/90 of 2 April 1990 reintroducing the levying of the customs duties on footwear falling within CN codes 6401 and 6402 originating in China to which the preferential tariff arrangements set out in Council Regulation 3896/89 apply (OJ L 88), OJ L 92/54, 7 April 1990

915/90 Commission Regulation of 6 April 1990 on arrangements for imports into the Community of certain textile products (category 5) originating in Indonesia, OJ L 94/5, 11 April 1990

938/90 Commission Regulation of 11 April 1990 reintroducing the levying of the customs duties applicable to footwear of $\mathrm{CN}$ codes 6401 and 6402 originating in Indonesia to which the preferential tariff arrangements set out in Council Regulation 3896/89 apply, OJ L 96/45, 12 April 1990

960/90 Commission Regulation of 11 April 1990 amending Annex III to Council Regulation 2135/89 with regard to certain textile products originating in the People's Republic of China (categories 4, 5, 6, 7, 8, 10, 16, 21, 27, 67 and 73), OJ L 98/5, 18 April 1990

1245/90 Commission Regulation of 8 May 1990 reintroducing the levying of the customs duties applicable to footwear of the CN codes 6404 and 64059010 (Order No. 10.0680) originating in Thailand, to which the preferential arrangements of Council Regulation 3896/89 apply, OJ L 121/20, 12 May 1990

$379 / 90$ Commission Regulation of 22 May 1990 re-establishing the levying of customs duties on woven fabrics of synthetic fibres (staple or waste), products of category 3 (order No. 40.0033), originating in India, to which the preferential tariff arrangements set out in Council Regulation 3897/89 apply, OJ L 133/19, 24 May 1990

$1380 / 90$ Commission Regulation of 22 May 1990 re-establishing the levying of customs duties on gloves, mittens and mitts, knitted or crocheted, products of category 10 (order No. 40.0100), originating in Pakistan, to which the preferential tariff arrangements set out in Council Regulation 3897/89 apply, OJ L 133/20, 24 May 1990 
1381/90 Commission Regulation of 22 May 1990 re-establishing the levying of customs duties on babies' garments and clothing accessories, products of category 68 (order No. 40.0680 ), originating in Thailand, to which the preferential tariff arrangements set out in Council Regulation 3897/89 apply, OJ L 133/21, 24 May 1990

1382/90 Commission Regulation of 22 May 1990 re-establishing the levying of customs duties on tents, products of category 91 (order No. 40.0910) and other made up textile articles, woven, products of category 112 (order No. 40.1120), originating in China, to which the preferential tariff arrangements set out in Council Regulation 3897/89 apply, Of L 133/22, 24 May 1990

1562/90 Commission Regulation of 7 June 1990 on arrangements for imports into the Community of certain textile products (category 5), originating in Indonesia, OJ L 148/19, 12 June 1990

$1639 / 90$ Commission Regulation of 15 June 1990 re-establishing the levying of customs duties on dresses, blouses and shirt-blouses of silk or of noil or of other waste silk, of textile fabric, products of category 159 (order No. 42.1590), originating in China, to which the preferential tariff arrangements set out in Council Regulation 3897/89 apply, OJ L 153/30, 19 June 1990

$1644 / 90$ Commission Regulation of 18 June 1990 on the opening of supplementary quotas for imports into the Community of certain textile products originating in certain third countries participating in the 1990 Berlin Trade Fairs, OJ L $154 / 5,20$ June 1990

Corrigendum to Commission Regulation $1644 / 90$ of 18 June 1990 on the opening of supplementary quotas for imports into the Community of certain textile products originating in certain third countries participating in the 1990 Berlin Trade Fairs (OJ L 154 of 20 June 1990), OJ L 206/31, 4 August 1990

$1695 / 90$ Commission Regulation of 21 June 1990 on arrangements for imports into the Community of certain textile products (category 26) originating in Pakistan, OJ L 158/10, 23 June 1990

1735/90 Commission Regulation of 21 June 1990 introducing prior Community surveillance of imports of certain types of footwear originating in South Korea and Taiwan, OJ L 161/12, 27 June 1990

1925/90 Council Regulation of 18 June 1990 on common rules for imports of certain textile products originating in the Union of Soviet Socialist Republics, OJ L $177 / 1,10$ July 1990

1980/90 Commission Regulation of 11 July 1990 reintroducing the levying of the customs duties applicable to footwear falling under CN codes 6401 and 6402 originating in Malaysia, to which the preferential arrangements of Council Regulation 3896/89 apply, OJ L 179/17, 12 July 1990

$1981 / 90$ Commission Regulation of 11 July 1990 reintroducing the levying of the customs duties applicable to footwear falling under CN codes 6401 and 6402 originating in the Philippines to which the preferential arrangements of Council Regulation 3896/89 apply, OJ L 179/18, 12 July 1990

$1982 / 90$ Commission Regulation of 11 July 1990 reintroducing the levying of the customs duties applicable to tableware falling under CN code 69120050 originating in Brazil to which the preferential arrangements of Council Regulation $3896 / 89$ apply, OJ L $179 / 19$, 12 July 1990 
2118/90 Commission Regulation of 24 July 1990 amending quantitative limits fixed for imports of certain textile products (categories 20 and 39 ) originating in the People's Republic of China, OJ L 193/21, 25 July 1990

$2163 / 90$ Commission Regulation of 26 July 1990 re-establishing the levying of the customs duties applicable to footwear falling within CN codes 6401 and 6402 , originating in Brazil, to which the preferential arrangements of Council Regulation No. 3896/89 apply, OJ L 197/44, 27 July 1990

$2164 / 90$ Commission Regulation of 26 July 1990 reintroducing the levying of the customs duties applicable to footwear within $\mathrm{CN}$ code 6403, originating in India, to which the preferential arrangements of Council Regulation No. 3896/89 apply, OJ L 197/45, 27 July 1990

$2165 / 90$ Commission Regulation of 26 . July 1990 reintroducing the levying of the customs duties applicable to footwear falling within CN codes 6404 and 640590 10 , originating in Pakistan, to which the preferential arrangements of Council Regulation No. 3896/89 apply, OJ L 197/46, 27 July 1990

2264/90 Commission Regulation 2264/90 of 1 August 1990 reintroducing the levying of customs duties applicable to footwear falling within $\mathrm{CN}$ codes 6404 and 64059010 , originating in the Philippines, to which the preferential arrangements of Council Regulation 3896/89 apply, OJ L 204/17, 2 August 1990

2540/90 Commission Regulation of 31 August 1990 reintroducing the levying of the customs duties applicable to woven fabrics of synthetic filament yarn products of category 33 (order 40.0330) originating in Thailand, to which the preferential tariff arrangements of Council Regulation 3897/89 apply, OJ L 237/91, 1 September 1990

2541/90 Commission Regulation of 31 August 1990 reintroducing the levying of the customs duties applicable to breeches, shorts and trousers products of category 6 (order 40.0060) men's or boy's suits and ensembles, other than knitted or crocheted products of category 16 (order 40.0160 ) originating in Pakistan, to which the preferential tariff arrangements of Council Regulation 3897/89 apply, OJ L 237/92, 1 September 1990

2542/90 Commission Regulation of 31 August 1990 reintroducing the levying of the customs duties applicable to nightshirts, pyjamas, bathrobes, knitted or crocheted, products of the category 24 (order 40.0240 ), women's or girls' dresses products of category 26 (order 40.0260 ) originating in Indonesia, to which the preferential tariff arrangements of Council Regulation 3897/89 apply, OJ L 237/94, 1 September 1990

2543/90 Commission Regulation of 31 August 1990 reintroducing the levying of the customs duties applicable to men's or boys' shirts, other than knitted or crocheted, products of category 8 (order 40.0080 ), terry towelling and similar woven terry fabrics of cotton, products of category 9 (order 40.0090), men's or boys' jackets excluding waister jackets and blazers, other than knitted or crocheted, products of category 17 (order 40.0170 ), women's or girls' dresses, products of category 26 (order 40.0260 ), table linen, toilet and kitchen products of category 39 (order 40.0390 ) originating in India, to which the preferential tariff arrangements of Council Regulation 3897/89 apply, OJ L 237/96, 1 September 1990

2664/90 Commission Regulation of 17 September 1990 reintroducing the levying of the customs duties applicable to track suits, products of category 73 (order 
40.0730) originating in Indonesia, the Philippines and Pakistan to which the preferential tariff arrangements of Council Regulation 3897/89 apply, OJ L 254/49, 18 September 1990

2665/90 Commission Regulation of 17 September 1990 reintroducing the levying of the customs duties applicable to twine, cordage, ropes and cables, of synthetic fibres products of category 90 (order 40.0900 ) originating in Hungary, to which the preferential tariff arrangements of Council Regulation 3897/89 apply, OJ L 254/50, 18 September 1990

2666/90 Commission Regulation of 17 September 1990 reintroducing the levying of the customs duties applicable to twine, cordage, ropes and cables, of synthetic fibres products of categroy 90 (order 40.0900), articles, products of category 98 (order 40.0980) originating in China, to which the preferential tariff arrangements of Council Regulation 3897/89 apply, OJ L 254/51, 18 September 1990

$2667 / 90$ Commission Regulation of 17 September 1990 reintroducing the levying of the customs duties applicable to pullovers and similar knitted or crocheted, products of category 5 (order 40.0050 ), articles, procts of category 98 (order 40.0980) originating in India, to which the preferential tariff arrangements of Council Regulation 3897/89 apply, OJ L 254/53, 18 September 1990

2668/90 Commission Regulation of 17 September 1990 reintroducing the levying of the customs duties applicable to products of category 7 (order 40.0070 ) originating in Malaysia, to which the preferential tariff arrangements of Council Regulation 3897/89 apply, OJ L 254/55, 18 September 1990

2669/90 Commission Regulation of 17 September 1990 reintroducing the levying of the customs duties applicable to underpants and briefs, products of category 13 (order 40.0130) originating in Thailand, to which the preferential tariff arrangements of Council Regulation 3897/89 apply, OJ L 254/56, 18 September 1990

2670/90 Commission Regulation of 17 September 1990 reintroducing the levying of the customs duties applicable to suits and ensembles, products of category 74 (order 40.0740) originating in Brazil, to which the preferential tariff arrangements of Council Regulation 3897/89 apply, OJ L 254/57, 18 September 1990

2671/90 Commission Regulation of 17 September 1990 reintroducing the levying of the customs duties applicable to articles knitted or crocheted products of categories 4 (order 40.0040) and 74 (order 40.0740) originating in Indonesia, to which the preferential tariff arrangements of Council Regulation 3897/89 apply, OJ L 254/58, 18 September 1990

2845/90 Commission Regulation of 28 September 1990 reintroducing the levying of the customs duties applicable to products of category 20 (order 40.0200 ) originating in Thailand, to which the preferential tariff arrangements of Council Regulation 3897/89 apply, OJ L 270/18, 2 October 1990

2970/90 Commission Regulation of 11 October 1990 re-establishing the levying of customs duties applicable to products of categories 16, 17 and 21 (order $40.0160,40.0210$ ) originating in Indonesia, to which preferential tariff arrangements of Council Regulation 3897/89 apply, Of 1990, L 283/9, 16 October 1990

2971/90 Commission Regulation of 11 October 1990 re-establishing the levying of customs duties applicable to products of category 21 (Order 40.0210 ) originat- 
ing in India, to which preferential tariff arrangements of Council Regulation $3897 / 89$ apply, OJ L 283/11, 16 October 1990

2972/90 Commission Regulation of 11 October 1990 re-establishing the levying of customs duties applicable to products of category 29 (Order 40.0290) originating in Thailand, to which preferential tariff arrangements of Council Regulation 3897/89 apply, OJ L 283/13, 16 October 1990

2973/90 Commission Regulation of 11 October 1990 re-establishing the levying of customs duties applicable to products of category 39 (Order 40.0390) originating in Pakistan, to which preferential tariff arrangements of Council Regulation 3897/89 apply, OJ L 283/14, 16 October 1990

3050/90 Council Regulation of 22 October 1990 amending Commission Regulation $1735 / 90$ introducing prior Community surveillance of imports of certain types of footwear originating in South Korea and Taiwan, OJ L 292/17, 24 October 1990

3058/90 Commission Regulation of 24 October 1990 amending the quantitative limits fixed by Council Regulation (EEC) $4134 / 86$ on the arrangements for imports of certain textile products originating in Taiwan, OJ L 294/18, 25 October 1990

3060/90 Commission Regulation of 24 October 1990 amending the quantitative limits fixed by Council Regulation 1925/90 on common rules for imports of certain textile products originating in the Union of Soviet Socialist Republics, OJ L 294/22, 25 October 1990

$3061 / 90$ Commission Regulation of 24 October amending the quantitative limits fixed by Council Regulation $4136 / 86$ on common rules for imports of certain textile products originating in third countries, OJ L 294/25, 25 October 1990

3143/90 Commission Regulation of 29 October 1990 amending Annexes III and IV bis to Council Regulation $4136 / 86$ with regard to certain textile products orginating in Sri Lanka (categories 6, 7, 8 and 21), OJ 1990, L 302/31, 31 October 1990

3385/90 Commission Regulation of 26 November 1990 re-establishing the levying of customs duties on products of category 18 (order No. 40.0180), originating in Pakistan to which the preferential tariff arrangements set out in Council Regulation 3897/89 apply, OJ L 327/11, 27 November 1990

3386/90 Commission Regulation of 26 November 1990 re-establishing the levying of customs duties on products of categories 23 (order No. 40.0230) and 37 (order No. 40.0370), originating in Indonesia, to which the preferential tariff arrangements set out in Council Regulation 3897/89 apply, OJ L 327/13, 27 November 1990

$3387 / 90$ Commission Regulation of 26 November 1990 re-establishing the levying of customs duties on products of category 65 (order No. 40.0650), originating in Argentina, to which the preferential tariff arrangements set out in Council Regulation 3897/89 apply, OJ L 327/15, 27 November 1990

3388/90 Commission Regulation of 26 November 1990 re-establishing the levying of customs duties on products of categories 65 (order No. 40.0650), 74 (order No. 40.0740) and 75 (order No. 40.0750) originating in China, to which the preferential tariff arrangements set out in Council Regulation 3897/89 apply, OJ L 327/17, 27 November 1990 
$3409 / 90$ Commission Regulation of 27 November 1990 re-establishing the levying of the customs duties applicable to certain products of the $\mathrm{CN}$ code 4104 originating in Argentina, to which the preferential arrangements of Council Regulation 3896/89 apply, OJ L 328/15, 28 November 1990

$3425 / 90$ Commission Regulation of 27 November 1990 re-establishing the levying of the customs duties applicable to products of category No. 15 (order No. 40.0150) originating in Pakistan, Thailand and Indonesia, to which the preferential tariff arrangements of Council Regulation No. 3897/89 apply, OJ L 330/26, 29 November 1990

$3426 / 90$ Commission Regulation of 27 November 1990 re-establishing the levying of the customs duties applicable to products of category No. 16 (order No. 40.0160) originating in India, to which the preferential tariff arrangements of Council Regulation No. 3897/89 apply, OJ L 330/28, 29 November 1990

$3427 / 90$ Commission Regulation of 27 November 1990 re-establishing the levying of the customs duties applicable to products of category No. 23 (order No. 40.0230) originating in Hungary, to which the preferential tariff arrangements of Council Regulation No. $3897 / 89$ apply, OJ L 330/29, 29 November 1990

$3428 / 90$ Commission Regulation of 27 November 1990 re-establishing the levying of the customs duties applicable to products of category No. 37 (order No. 40.0370) originating in Pakistan, to which the preferential tariff arrangements of Council Regulation No. 3897/89 apply, OJ L 330/30, 29 November 1990

3429/90 Commission Regulation of 27 November 1990 re-establishing the levying of the customs duties applicable to products of category No. 75 (order No. 40.0750) originating in Thailand, to which the preferential tariff arrangements of Council Regulation No. $3897 / 89$ apply, OJ L 330/32, 29 November 1990

$3430 / 90$ Commission Regulation of 27 November 1990 re-establishing the levying of the customs duties applicable to products of category No. 22 (order No. 40.0220 ) and the products of category No. 127 a (order no 42,1271) originating in India, to which the preferential tariff arrangements of Council Regulation No. 3897/89 apply, OJ L 330/34, 29 November 1990

$3431 / 90$ Commission Regulation of 27 November 1990 re-establishing the levying of the customs duties applicable to products of category No. $146 \mathrm{~A}$ (order No. 42.1461) originating in Mexico, to which the preferential tariff arrangements of Council Regulation No. 3897/89 apply, OJ L 330/36, 29 November 1990

$3479 / 90$ Commission Regulation of 30 November 1990 re-establishing the levying of the customs duties applicable to products of $\mathrm{CN}$ code 4203 originating in India, to which the preferential tariff arrangements of Council Regulation 3896/89 apply, OJ L 336/67, 1 December 1990

3506/90 Commission Regulation of 3 December 1990 re-establishing the levying of the customs duties on products falling within CN code 4203 , originating in Pakistan, to which the preferential tariff arrangements set out in Council Regulation 3896/89 apply, OJ L 338/14, 5 December 1990

3799/90 Commission Regulation of 21 December 1990 re-establishing the levying of the customs duties applicable to the products of category No. 27 (order No. 40.0270) originating in India, to which the preferential tariff arrangements of Council Regulation 3897/89 apply, OJ L 365/36, 28 December 1990 
Agreements and Unilateral Acts Concerning Agricultural Products and Fishery

90/114 Council Decision of 22 January 1990 concerning the conclusion of exchanges of letters adjusting the Agreement between the European Economic Community and the Eastern Republic of Uruguay on trade in mutton and lamb, OJ L 69/61, 16 March 1990

Agreement in the form of exchanges of letters adjusting the Agreement between the European Economic Community and the Eastern Republic of Uruguay on trade in mutton and lamb, OJ L 69/62, 16 March 1990

90/149 Council Decision of 22 March 1990 authorizing the Portuguese Republic to extend until 8 April 1991 the agreement on mutual fishery relations with the Republic of South Africa, OJ L 81/37, 28 March 1990

90/173 Council Decision of 26 March 1990 concerning the adjustment of the voluntary restraint Agreements with certain third countries in the sheepmeat and goatmeat sector, OJ L 95/1, 12 April 1990

Agreement in the form of an Exchange of Letters relating to the 1982 Agreement between the European Economic Community and the People's Republic of Bulgaria on trade in the sheepmeat and goatmeat sector, OJ L 95/2, 12 April 1990

Agreement in the form of an Exchange of Letters relating to the 1981 Agreement between the European Economic Community and the Republic of Hungary on trade in the sheepmeat and goatmeat sector, OJ L 95 7,12 April 1990

Agreement in the form of an Exchange of Letters relating to the 1981 Agreement between the European Economic Community and the Republic of Poland on trade in the sheepmeat and goatmeat sector, OJ L 95/12, 12 April 1990

Agreement in the form of an Exchange of Letters relating to the 1987 Agreement between the European Economic Community and the German Democratic Republic on trade in the sheepmeat and goatmeat sector, OJ L 95/17, 12 April 1990

Agreement in the form of an Exchange of Letters relating to the 1982 Agreement between the European Economic Community and the Czechoslovak Socialist Republic on trade in the sheepmeat and goatmeat sector, OJ L 95/21, 12 April 1990

Agreement in the form of an Exchange of Letters relating to the 1981 Agreement between the European Economic Community and the Socialist Federal Republic of Yugoslavia on trade in the sheepmeat and goatmeat sector, OJ L 95/25, 12 April 1990

90/637 Council Decision of 22 October 1990 concerning the conclusion of a Protocol renewing the Cooperation Agreement between the European Economic Community and the Kingdom of Thailand on manioc production, marketing and trade, OJ L 347/23, 12 December 1990

Protocol renewing the Cooperation Agreement between the European Economic Community and the Kingdom of Thailand on manioc production, marketing and trade, OJ L 347/24, 12 December 1990 
Information concerning the signing of the Protocol renewing the Cooperation Agreement between the European Economic Community and the Kingdom of Thailand on manioc production, marketing and trade, OJ L 347/26, 12 December 1990

479/90 Commission Regulation of 26 February 1990 derogating from Regulation 19/82 laying down detailed nules for applying Regulation 2641/80 with regard to imports of sheepmeat and goatmeat products originating in certain nonmember countries, OJ L 51/18, 27 February 1990

525/90 Commission Regulation of 28 February 1990 amending Regulation 19/82 laying down detailed rules for applying Council Regulation 2641/80 with regard to imports of sheepmeat and goatmeat products originating in certain nonmember countries, OJ L 53/84, 1 March 1990

952/90 Commission Regulation of 11 April 1990 derogating from Regulation 19/82 and 3653/85 and amending Regulation $479 / 90$ as regards imports of sheepmeat and goatmeat products originating in certain third countries, OJ L $96 / 73,12$ April 1990

1249/90 Commission Regulation of 11 May 1990 derogating from Regulation 19/82 laying down detailed rules for applying Council Regulation 2641/80 with regard to imports of sheepmeat and goatmeat products originating in certain nonmember countries, OJ L 121/26, 12 May 1990

90/259 Commission Decision of 16 May 1990 on the quantities of sheepmeat and goatmeat that may be imported in 1990 into certain sensitive marketing zones from certain non-member countries, OJ L 145/48, 8 June 1990

1580/90 Commission Regulation of 13 June 1990 derogating from Regulation 19/82 and $3653 / 85$ as regards imports of sheepmeat and goatmeat products originating in certain third countries, OJ L 150/7, 14 June 1990

1868/90 Commission Regulation of 2 July 1990 amending Regulation 19/82 laying down detailed rules for applying Council Regulation 2641/80 with regard to imports of sheepmeat and goatmeat products originating in certain non-member countries, OJ L 170/39, 3 July 1990

2085/90 Commission Regulation of 20 July 1990 derogating from Regulation 19/82 laying down detailed rules for applying Council Regulation 2641/80 with regard to imports of sheepmeat and goatmeat products originating in certain nonmember countries, OJ L 190/31, 21 July 1990

2569/90 Commission Regulation of 5 September 1990 amending Regulation 19/82 laying down detailed rules for applying Council Regulation 2641/90 with regard to imports of sheepmeat and goatmeat products originating in certain nonmember countries, OJ L 243/15, 6 September 1990

$3392 / 90$ Commission Regulation 3392/90 of 26 November 1990 concerning the quantities of sheepmeat and goatmeat products which may be imported from Romania during 1990, OJ L 327/25, 27 November 1990

3785/90 Commission Regulation of 19 December 1990 amending Regulation 19/82 laying down detailed rules for applying Council Regulation 2641/90 with regard to imports of sheepmeat and goatmeat products originating in certain nonmember countries, OJ L 364/23, 28 December 1990

90/4 Commission Decision of 19 December 1989 authorizing the United Kingdom to extend intra-Community surveillance in respect of bananas originating in 
certain third countries and put into free circulation in other Member States, OJ L 2/30, 5 January 1990

90/8 Commission Decision of 19 December 1989 amending Decision 89/15/EEC on the importations of live animals and fresh meat from certain third countries, OJ L 7/8, 10 January 1990

90/12 Commission Decision of 20 December 1989 amending Decision 89/310/EEC on the quantities of sheepmeat and goatmeat that may be imported in 1989 into certain sensitive marketing zones from certain non-member countries, OJ L 8/68, 11 January 1990

90/58 Commission Decision of 5 February 1990 concerning animal health conditions and veterinary certification for imports of fresh meat from Chile, OJ L 40/15, 14 February 1990

$491 / 90$ Council Regulation of 26 February 1990 amending Regulation 2967/89 relating to the continued import of New Zealand butter into the United Kingdom on special terms, OJ L 53/4, 1 March 1990

683/90 Commission Regulation of 21 March 1990 amending Commission Regulation $3919 / 89$ laying down detailed rules for the application in the pigmeat sector of Council Regulation 3899/89 reducing for 1990 the levies on certain agricultural products originating in developing countries, OJ L 76/9, 22 March 1990

684/90 Commission Regulation of 21 March 1990 amending Commission Regulation $3920 / 89$ laying down detailed rules for the application in the poultrymeat sector of Council Regulation 3899/89 reducing for 1990 the levies on certain agricultural products originating in developing countries, OJ L 76/11, 22 March 1990

90/135 Commission Decision of 7 March 1990 relating to the plans of certain third countries concerning examination of residues of fresh meat for substances other than those having a hormonal action, OJ L 76/24, 22 March 1990

90/164 Commission Decision of 28 March 1990 amending Dec. 90/135/EEC relating to the plans of certain third countries concerning examination of residues of fresh meat for substances other than those having a hormonal action, OJ $\mathrm{L}$ 91/32, 6 April 1990

90/262 Commission Decision of 5 June 1990 amending Decision 90/135/EEC relating to the plans of certain third countries concerning examination of residues of fresh meat for substances other than those having a hormonal action, OJ L 149/22, 13 June 1990

90/152 Commission Decision of 22 March 1990 amending Decision 89/15/EEC on the importation of live animals and fresh meat from certain third countries, OJ $\mathrm{L}$ 81/40, 28 March 1990

90/338 Commission Decision of 14 June 1990 amending Decision 89/15/EEC on the importation of live animals and fresh meat from certain third countries, OJ L 162/42, 28 June 1990

$2198 / 90$ Commission Regulation of 27 July 1990 on protective measures applicable to imports of frozen strawberries, frozen raspberries, provisionally preserved strawberries and provisionally preserved raspberries originating in Poland, OJ L 198/53, 28 July 1990 
2199/90 Commission Regulation of 27 July 1990 on protective measures applicable to imports of frozen raspberries and provisionally preserved raspberries originating in Yugoslavia, OJ L 198/55, 28 July 1990

90/350 Commission Decision of 27 June 1990 authorizing the Italian Republic to apply intra-Community surveillance in respect of bananas originating in certain third countries and put into free circulation in the other Member States, OJ L 171/27, 4 July 1990

2428/90 Commission Regulation of 21 August 1990 on imports of preserved mushrooms from third countries and amending Regulation 1851/90 on the issuing of import licences for preserved cultivated mushrooms originating in China, OJ L 228/16, 22 August 1990

$3604 / 90$ Commission Regulation of 13 December 1990 fixing the quotas applying to imports into Spain of beef and veal products from third countries, OJ L 350/58, 14 December 1990

3797/90 Commission Regulation of 21 December 1990 on protective measures applicable to imports of certain semi-processed red fruits originating in Poland and Yugoslavia, OJ L 365/22, 28 December 1990

\section{Agreements and Unilateral Acts Concerning Other Products}

90/510 First Council Decision of 9 October 1990 on the extension of the legal protection of topographies of semiconductor products to persons from certain countries and territories, OJ L 285/29, 17 October 1990

90/511 Second Council Decision of 9 October 1990 on the extension of the legal protection of topographies of semiconductor products to persons from certain countries and territories, OJ L 285/31, 17 October 1990

$155 / 90$ Commission Regulation of 22 January 1990 amending Regulation 3856/89 laying down implementing procedures for the import arrangements applicable to products covered by $\mathrm{CN}$ codes $07141091,07141099,07149011$ and 07149019 originating in the present Contracting Parties to the GATT other than Thailand, OJ L 18/28, 23 January 1990

731/90 Commission Regulation of 26 March 1990 amending Council Regulation 3677/86 laying down provisions for the implementation of Regulation $1999 / 85$ on inward processing relief arrangements, OJ L 81/14, 28 March 1990

Corrigendum to Commission Regulation 731/90 of 26 March 1990 amending Council Regulation 3677/86 laying down provisions for the implementation of Regulation 1999/85 on inward processing relief arrangements (OJ L 81/14), OJ L 171/29, 4 July 1990

846/90 Commission Regulation of 2 April 1990 reintroducing the levying of the customs duties on urea falling within CN code 31021010 originating in Brazil to which the preferential tariff arrangements set out in Council Regulation 3896/89 apply, OJ L 88/30, 3 April 1990

$847 / 90$ Commission Regulation of 2 April 1990 reintroducing the levying of the customs duties on $1,2,3,4,5,6$-hexachlorocyclohexane falling within $\mathrm{CN}$ code 29035100 originating in China to which the preferential tariff arrangements set out in Council Regulation 3896/89 apply, OJ L 88/31, 3 April 1990 
939/90 Commission Regulation of 11 April 1990 reintroducing the levying of the customs duties applicable to copper bars, rods, profiles, tubes and pipes of $\mathrm{CN}$ codes ex 7407 and 7411 originating in Mexico to which the preferential tariff arrangements set out in Council Regulation 3896/89 apply, OJ L 96/46, 3 April 1990

940/90 Commission Regulation of 11 April 1990 reintroducing the levying of the customs duties applicable to reception apparatus of $\mathrm{CN}$ codes 8527,8528 and 8529 originating in China to which the preferential tariff arrangements set out in Council Regulation 3896/89 apply, Of L 96/48, 12 April 1990

941/90 Commission Regulation of 11 April 1990 reintroducing the levying of the customs duties applicable to reception apparatus of $\mathrm{CN}$ codes 8527, 8528 and 8529 originating in Malaysia to which the preferential tariff arrangements set out in Council Regulation 3896/89 apply, OJ L 96/50, 12 April 1990

$1244 / 90$ Commission Regulation of 8 May 1990 reintroducing the levying of the customs duties applicable to products of the CN code 29309010 (Order No. 10.0290) originating in China, to which the preferential arrangements of Council Regulation 3896/89 apply, OJ L 121/19, 12 May 1990

1274/90 Council Regulation of 7 May 1990 applying supplementary generalized tariff preferences in respect of certain industrial products originating in countrics benefitting from generalized preferences and sold at the Berlin 'Partners in Progress' Fair, OJ L 126/1, 16 May 1990

$1631 / 90$ Commission Regulation of 15 June 1990 re-establishing the levying of customs duties on prepared unrecorded media falling within $C N$ codes 8523 and 8524 , originating in China, to which the preferential tariff arrangements set out in Council Regulation 3896/89 apply, OJ L 153/7, 19 June 1990

1754/90 Commission Regulation of 27 June 1990 re-establishing the levying of customs duties on citric acid falling within $\mathrm{CN}$ code 29181400 , originating in Indonesia, to which the preferential arrangements of Council Regulation 3896/89 apply, OJ L 162/17, 28 June 1990

$2162 / 90$ Commission Regulation of 26 July 1990 re-establishing the levying of the customs duties applicable to polymers of vinyl chloride falling within $\mathrm{CN}$ code 3904, originating in Poland, to which the preferential arrangements of Council Regulation No. 3896/89 apply, OJ L 197/43, 27 July 1990

$2166 / 90$ Commission Regulation of 26 July 1990 reintroducing the levying of the customs duties applicable to television receivers falling within $\mathrm{CN}$ codes 8528 originating in Hungary to which the preferential arrangements of Council Regulation No. 3896/89 apply, OJ L 197/47, 27 July 1990

$2167 / 90$ Commission Regulation of 26 July 1990 reintroducing the levying of the custom duties applicable to toys falling within $\mathrm{CN}$ code 9503 originating in China, to which the preferential arrangements of Council Regulation No. $3896 / 89$ apply, OJ L 197/48, 27 July 1990

2284/90 Commission Regulation of 2 August 1990 reintroducing the levying of the customs duties applicable to synthetic camphor falling within CN code ex 2914 2100 , originating in China, to which the preferential arrangements of Council Regulation 3896/89 apply, OJ L 205/18, 3 August 1990

2538/90 Commission Regulation of 31 August 1990 reintroducing the levying of the customs duties applicable to products of CN codes 39041000,39042100 and 
39042200 originating in Mexico, to which the preferential arrangements of Council Regulation 3896/89 apply, OJ L 237/89, 1 September 1990

2539/90 Commission Regulation of 31 August 1990 reintroducing the levying of the customs duties applicable to jewellery of CN codes 71131100 and 71131900 originating in Thailand, to which the preferential tariff arrangements of Council Regulation 3896/89 apply, OJ L 237/90, 1 September 1990

2544/90 Commission Regulation of 31 August 1990 reintroducing the levying of customs duties applicable to products of CN codes 29372100 and 29372910 originating in China, to which the preferential arrangements of Council Regulation 3896/89 apply, OJ L 237/98, 1 September 1990

2600/90 Commission Regulation of 7 September 1990 re-establishing the levying of customs duties on products falling within CN code 35030010 originating in Brazil to which the preferential tariff arrangements set out in Council Regulation 3896/89 apply, OJ L 245/10, 8 September 1990

Corrigendum to Commission Regulation 2600/90 of 7 September 1990 reestablishing the levying of customs duties on products falling within $\mathrm{CN}$ code 35030010 originating in Brazil to which the preferential tariff arrangements set out in Council Regulation 3896/89 apply (OJ L 245 of 8 September 1990), OJ L 251/35, 14 September 1990

90/459 Commission Decision of 1 August 1990 authorizing the Member States to institute intra-Community surveillance of the importation for home use of certain iron and steel products originating in certain third countries and covered by the Treaty establishing the European Coal and Steel Community and in free circulation in the Community, OJ L 240/1, 3 September 1990

90/661 Commission Decision of 12 December 1990 amending Decision 90/459 authorizing the Member States to institute intra-Community surveillance of the importation for home use of certain iron and steel products originating in certain third countries and covered by the Treaty establishing the European Coal and Steel Community and in free circulation in the Community, OJ L 355/17, 18 December 1990

2903/90 Commission Decision of 8 October 1990 prohibiting alignment on offers of steel products originating from certain third countries, OJ L 277/26, 9 October 1990

$3211 / 90$ Council Regulation of 29 October 1990 amending Regulation 3896/89, $3897 / 89$ and $3898 / 89$ in respect of the system of generalized tariff preferences applied to certain products originating in Bolivia, Colombia, Ecuador and Peru, OJ L 308/1, 8 November 1990

$3248 / 90$ Commission Regulation of 9 November 1990 re-establishing the levying of the customs duties applicable to products of CN code 29157010 originating in Malaysia, to which the preferential tariff arrangements of Council Regulation 3896/89 apply, OJ L 311/20, 10 November 1990

$3279 / 90$ Commission Regulation of 13 November 1990 re-establishing the levying of customs duties applicable to the products falling within CN code 29224100 originating in Mexico, to which the preferential arrangements of Council Regulation 3896/89 apply, OJ L 315/18, 15 November 1990

$3280 / 90$ Commission Regulation of 13 November 1990 re-establishing the levying of customs duties applicable to the products falling within CN code 35030010 
originating in Pakistan, to which the preferential arrangements of Council Regulation 3896/89 apply, OJ L 315/19, 15 November 1990

3407/90 Commission Regulation of 27 November 1990 re-establishing the levying of the customs duties applicable to the products of the CN code 3105 originating in Poland, to which the preferential arrangements of Council Regulation $3896 / 89$ apply, OJ L 328/13, 28 November 1990

3408/90 Commission Regulation of 27 November 1990 re-establishing the levying of the customs duties applicable to the products of the CN codes 3903, 391520 00,39203000 and 39209950 originating in Mexico, to which the preferential arrangements of Council Regulation 3896/89 apply, OJ L 328/14, 28 November 1990

3410/90 Commission Regulation of 27 November 1990 re-establishing the levying of the customs duties applicable to the products of the CN code 85416000 originating in Malaysia, to which the preferential arrangements of Council Regulation 3896/89 apply, OJ L 328/16, 28 November 1990

90/542 Decision of the representatives of the Governments of the Member States of the European Coal and Steel Community, meeting within the Council of 29 October 1990 amending the scope of Decision 89/645/ECSC in respect of the system of generalized tariff preferences applied to certain iron and stecl products originating in Bolivia, Colombia, Peru and Ecuador, OJ L 308/39, 8 November 1990

3478/90 Commission Regulation of 30 November 1990 re-establishing the levying of the customs duty applicable to the products of $\mathrm{CN}$ code 28170000 originating in China, to which the preferential tariff arrangements of Council Regulation 3896/89 apply, OJ L 336/66, 1 December 1990

$3491 / 90$ Council Regulation of 26 November 1990 on imports of rice originating in Bangladesh, OJ L 337/1, 4 December 1990

3494/90 Council Regulation of 27 November 1990 opening and providing for the administration of a Community quota for chemically pure fructose originating in third countries not bound to the Community by a preferential trade agreement (1991), OJ L 337/9, 4 December 1990

3581/90 Commission Regulation of 11 December 1990 re-establishing the levying of the customs duties applicable to the products of $\mathrm{CN}$ code 29400090 originating in China, to which the preferential tariff arrangements of Council Regulation 3896/89 apply, OJ L 349/8, 13 December 1990

3610/90 Council Regulation of 11 December 1990 opening and providing for the administration of Community tariff quotas for certain agricultural, chemical and industrial products (1991), OJ L 351/2, 15 December 1990

$3611 / 90$ Council Regulation of 11 December 1990 opening and providing for the administration of an autonomous Community tariff quota for newsprint (1990) and extending this quota to include certain other types of paper, OJ $\mathrm{L} 351 / 5,15$ December 1990

3618/90 Commission Regulation of 13 December 1990 reintroducing the levying of the customs duties applicable to the products of the CN code 39012000 originating in Mexico, to which the preferential arrangements of Council Regulation $3896 / 89$ apply, Of L 351/23, 15 December 1990 
3668/90 Commission Regulation of 18 December 1990 laying down implementing procedures for the import arrangements applicable to products covered by $\mathrm{CN}$ codes $07141091,07141099,07149011$ and 07149019 originating in the present Contracting Parties to the GATT other than Thailand, OJ L 356/18, 19 December 1990

$3751 / 90$ Commission Regulation of 20 December 1990 re-establishing the levying of the customs duties applicable to the products falling within $\mathrm{CN}$ code 7013 originating in China, to which the preferential arrangements of Council Regulation 3896/89 apply, OJ L 360/41, 22 December 1990

\section{Community Acts Concerning German Unification}

* Agreement in the form of an Exchange of Letters relating to the 1987 Agreement between the European Economic Community and the German Democratic Republic on trade in the sheepmeat and goatmeat sector, OJ L 95/17, 12 April 1990

1794/90 Council Regulation of 28 June 1990 on transitional measures concerning trade with the German Democratic Republic, OJ L 166/1, 29 June 1990

1795/90 Commission Regulation of 29 June 1990 conceming the methods of implementation of Council Regulation 1794/90 on the transitional measures for trade with the German Democratic Republic, OJ L 166/3, 29 June 1990

$1796 / 90$ Commission Decision of 29 June 1990 on the suspension of customs duties and quantitative restrictions for products falling within the ECSC Treaty coming from the German Democratic Republic, OJ L 166/5, 29 June 1990

Corrigendum to Commission Decision $1796 / 90$ of 29 June 1990 on the suspension of customs duties and quantitative restrictions for products falling within the ECSC Treaty coming from the German Democratic Republic (OJ L 166/5), OJ L 186/26, 18 July 1990

2060/90 Council Regulation of 16 July 1990 on transitional measures concerning trade with the German Democratic Republic in the agriculture and fisheries sector, OJ L 188/1, 20 July 1990

2066/90 Commission Regulation of 19 July 1990 on the consequences of the non-fixing of a rate of refund on certain agricultural products exported to the German Democratic Republic in the form of goods not covered by Annex II to the Treaty, OJ L 188/23, 20 July 1990

2252/90 Commission Regulation 2252/90 of 31 July 1990 concerning the methods of implementation of Council Regulation 2060/90 on transitional measures concerning trade with the German Democratic Republic in the agriculture and fisheries sector, OJ L 203/61, 1 August 1990

Corrigendum to Commission Regulation 2252/90 of 31 July 1990 concerning the methods of implementation of Council Regulation 2060/90 on transitional measures conceming trade with the German Democratic Republic in the agriculture and fisheries sector (OJ L 203 of 1 August 1990), OJ L 219/63, 14 August 1990

2684/90 Council Regulation of 17 September 1990 on interim measures applicable after the unification of Germany, in anticipation of the adoption of transitional 
measures by the Council either in cooperation with, or after consultation of, the European Parliament, OJ L 263/1, 26 September 1990

2761/90 Commission Regulation of 27 September 1990 on stocks of agricultural products held in the territory of the former German Democratic Republic, OJ L 267/1, 29 September 1990

2762/90 Commission Regulation of 27 September 1990 on interim measures applicable to trade in the agricultural sector after the unification of Germany, OJ L 267/3, 29 September 1990

2764/90 Commission Regulation of 27 September 1990 on provisional measures applicable in the cereals sector after the unification of Germany, OJ L 267/9, 29 September 1990

2765/90 Commission Regulation of 27 September 1990 laying down provisional measures applicable in the sugar sector following the unification of Germany, OJ L 267/11, 29 September 1990

2768/90 Commission Regulation of 27 September 1990 on provisional measures applicable in the milk and milk products sector after the unification of Germany, OJ L 267/15, 29 September 1990

2769/90 Commission Regulation of 27 September 1990 on interim measures applicable in the beef and veal sector after the unification of Germany, OJ L 267/17, 29 September 1990

2770/90 Commission Regulation of 27 September 1990 on interim measures applicable after the unification of Germany in the sheepmeat and goatmeat sector, OJ L 267/19, 29 September 1990

2771/90 Commission Regulation of 27 September 1990 laying down interim measures applicable in the pigmeat sector after the unification of Germany, OJ L 267/21, 29 September 1990

2772/90 Commission Regulation of 27 September 1990 on interim measures applicable in the egg and poultrymeat sectors after the unification of Germany, OJ L 267/23, 29 September 1990

2774/90 Commission Regulation of 27 September 1990 on interim measures applicable in the fruit and vegetables sector after the unification of Germany, OJ L 267/26, 29 September 1990

2775/90 Commission Regulation of 27 September 1990 on interim measures applicable after the unification of Germany in anticipation of the adoption of transitional measures by the Council in the wine sector, OJ L 267/28, 29 September 1990

$2776 / 90$ Commission Regulation of 27 September 1990 on transitional measures to be applied in the wine sector after the unification of Germany in the territory of the former German Democratic Republic, OJ L 267/30, 29 September 1990

2777/90 Commission Regulation of 27 September 1990 on interim measures applicable in the raw tobacco sector after the unification of Germany, OJ L 267/32, 29 September 1990

2778/90 Commission Regulation of 27 September 1990 on interim measures applicable in the seeds sector after the unification of Germany, OJ L 267/34, 29 September 1990

90/481 Commission Decision of 27 September 1990 introducing interim measures relating to the unification of Germany, OJ L 267/37, 29 September 1990 
$3112 / 90$ Commission Regulation of 26 October 1990 amending Regulation 2768/90 on provisional measures applicable in the milk and milk products sector after the unification of Germany, OJ L 296/51, 27 October 1990

90/640 Council Decision of 3 December 1990 authorizing the Federal Republic of Germany to grant an exemption from Articles 14 and 15 of the Sixth Dir $77 / 388$ on the harmonization of the laws of the Member States relating to turnover taxes for Soviet armed forces stationed on the territory of the Federal Republic of Germany, OJ L 349/19, 13 December 1990

3568/90 Council Regulation of 4 December 1990 on the introduction of transitional tariff measures for Bulgaria, Czechoslovakia, Hungary, Poland, Romania, the USSR and Yugoslavia until 31 December 1992 to take account of German unification, OJ L 353/1, 17 December 1990

3573/90 Council Regulation of 4 December 1990 amending, as a result of German unification, Regulation 4055/86 applying the principle of freedom to provide services to maritime transport between Member States and between Member States and third countries, OJ L 353/16, 17 December 1990

$3714 / 90$ Commission Regulation of 19 December 1990 on transitional measures on trade in certain fishery products with the USSR after the unification of Germany, OJ L 358/36, 21 December 1990

$3788 / 90$ Commission Decision of 19 December 1990 on the introduction of transitional tariff measures for products covered by the Treaty establishing the ECSC for Bulgaria, Czechoslovakia, Hungary, Poland, Romania, the USSR and Yugoslavia until 31 December 1992 to take account of German unification, OJ L 364/27, 28 December 1990

\section{Community Acts Concerning the Gulf Crisis}

2340/90 Council Regulation of 8 August 1990 preventing trade by the Community as regards Iraq and Kuwait, OJ L 213/1, 9 August 1990

Corrigendum to Council Regulation $2340 / 90$ of 8 August 1990 preventing trade by the Community as regards Iraq and Kuwait (OJ L 213 of 9 August 1990), OJ L 216/28, 11 August 1990

90/414 Decision of the Representatives of the Governments of the Member States of the European Coal and Steel Community, meeting within the Council of 8 August 1990 preventing trade as regards Iraq and Kuwait, OJ L 213/3, 9 August 1990

Corrigendum to Decision 90/414 of the Representatives of the Governments of the Member States of the European Coal and Steel Community, meeting within the Col, of 8 August 1990, preventing trade as regards Iraq and Kuwait (OJ L 213 of 9 August 1990) OJ L 216/28, 11 August 1990

3155/90 Council Regulation of 29 October 1990 extending and amending Regulation 2340/90 preventing trade by the Community as regards Iraq and Kuwait, OJ L 304/1, 1 November 1990

3557/90 Council Regulation of 4 December 1990 on financial aid for the countries most directly affected by the Gulf crisis, OJ L 347/1, 12 December 1990 
